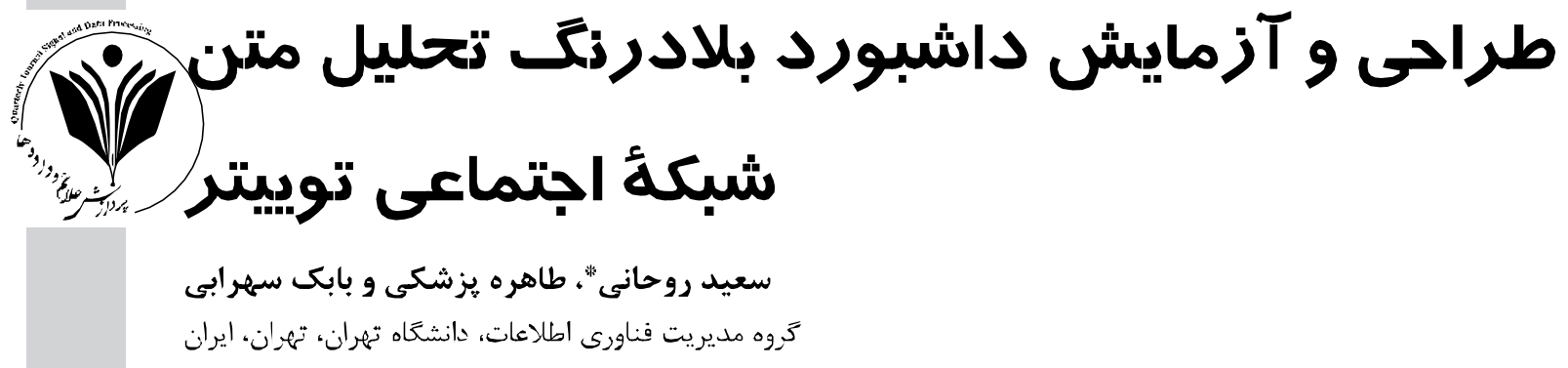

جكبـ يكى از مباحث يزوهشى مههم امروز در حوزه فناورى اطلاعات و فناورى استفاده از دانش نهفته در دادههايى است كه امروزه با سرعت بالا،

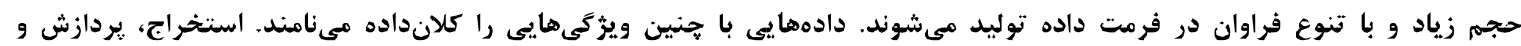

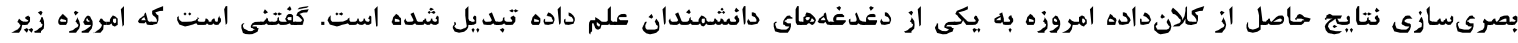

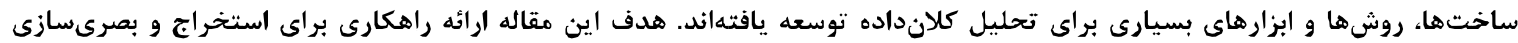

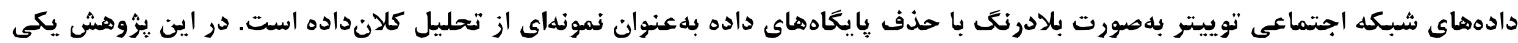

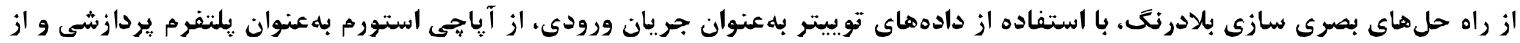

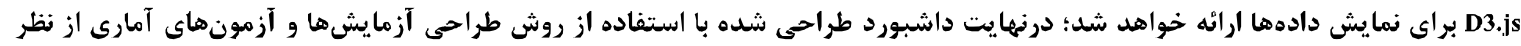

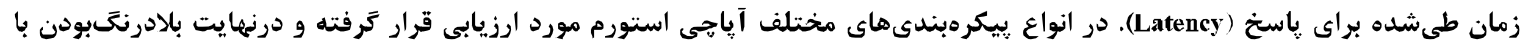

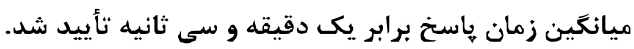
وازَّان كليدى: كلان داده، بصرىسازى، داشبورد بلادرنى

\title{
Design and Test of the Real-time Text mining dashboard for Twitter
}

\author{
Saeed Rouhani*, Tahereh Pezeshki \& Babak Sohrabi \\ Department of Information Technology Management, University of Tehran, Tehran, Iran
}

\begin{abstract}
One of today's major research trends in the field of information systems is the discovery of implicit knowledge hidden in dataset that is currently being produced at high speed, large volumes and with a wide variety of formats. Data with such features is called big data. Extracting, processing, and visualizing the huge amount of data, today has become one of the concerns of data science scholars.

The impact of big data on information analysis can be traced to four different parts. The first part is data extraction and processing, the second part is data analysis, the third part is data storage, and finally the visualization of the data. In the field of big data processing, in various studies, different categories have been presented. For example, in the studies of IIashim et al., big data processing is divided into two categories. These two types are: batch and real time. These two categories of processing, which nowadays are standard in any comprehensive big data solution, also have been introduced in Abawajy studies: batch processing is related to offline processing, and real-time processing is usually used to analyze the streaming data without any need to storage of data on disk. $\Lambda$ s data flows from various sources, the data is analyzed and processed real time, for immediate insight. $\Lambda$ s today's world is rapidly changing and survival in today's competitive


world requires instant decision-making based on flows of data, streaming data analysis is becoming increasingly important.

On the other hand, one of the great valuable sources of streaming data is the data generated by social networks' users such as Twitter. Social networks data sourees are very rich sources for analysis as they come from the opinions and opinions of their users.

As discussed earlier, and since previous studies such as Flash's studies have focused more on batch analysis (offline data), this study has attempted to investigate a variety of tools and infrastructures related to big streaming data, and finally design a real-time dashboard based on Twitter social network streaming data.

The following article addresses two research questions: 1) How to design and implement a real-time dashboard based on social networks data? 2) Which different configurations are best suited for real-time dashboard analysis and visualization?

In other words, the purpose of this article is to provide a solution for extracting and visualizing Twitter's social network streaming data by deleting databases, as an examples of big data real time analysis. In this research, we used Twitter streaming data as an input, $\Lambda$ pache Storm as a processing platform and D3.js as a visualization tool.

Finally, the designed dashboard was evaluated using Design of Experiment method and other statistical tests in various types of Apache Storm configurations and eventually it was proved that the dashboard is real time with an average response time for 1 minute and 30 seconds.

Keywords: Big data, visualization, real time dashboard

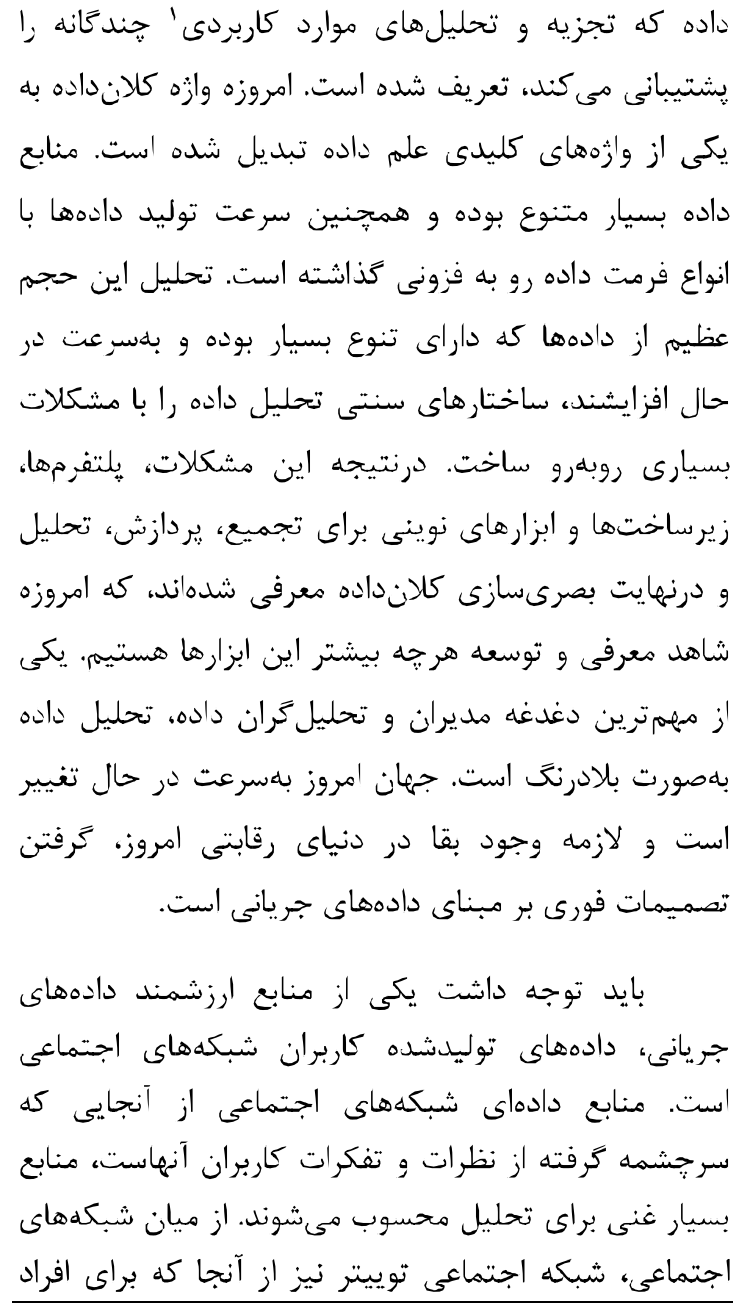

${ }^{1}$ Usecases

$$
\begin{aligned}
& \text { - } 1 \\
& \text { مىدانيم با يِشرفت سريع فناورى، حجم دادههايى كله در } \\
& \text { اين بستر منتقل و ذخيره مىشوند، رو به فزونى كذاشته } \\
& \text { است. در جنين شرايطى است كه وازه كلانهاده يا به عرصه } \\
& \text { ظهوز مي حذارد. كلانداده با ويثگى هاى اصلى حجم, بالا، } \\
& \text { سرعت بالا و تنوع در فرمت داده شناخته شده و در ابتدا } \\
& \text { جهت عموميىسازى مفهوم كلانداده، انجمنهاى مطالعاتى و } \\
& \text { رسانهها به اصوات يكسان در ابتداى تعريف توجه كرده و از } \\
& \text { اصطلاح 3V، حجم, (Volumc)، سرعت (Velocity) و تنوع } \\
& \text { استفاده مي كنند. سايرين نيز از اين زوش استفاده } \\
& \text { كرده و Vاى ديكر نظير ارزش (Value)، يا قابليت } \\
& \text { تغييريذيرى (Variability) جهت بهبود و ارتقاى معنا به } \\
& \text { تعريف بالا افزودهاند [1]. در سالهاى اخير كلانداده با } \\
& \text { ويثزى هايى كه براى آن برشمرده مىشود، شناخته شده و } \\
& \text { تعريف مىشود. سازمان مطالعاتى كارتنر مىتواند كزينه } \\
& \text { معتبرى براى شناسايى معانى رايج و مورد استفاده در اين }
\end{aligned}
$$

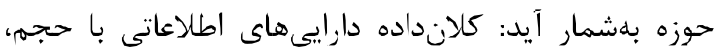

$$
\begin{aligned}
& \text { سرعت و تنوع بالا بوده كد براى افزايث درك و قدرت } \\
& \text { تصميمَگيرى، نيازمند يردازش اطلاعاتى از نوع نوآورانه و } \\
& \text { مؤثر است؛ همجنين به زَزارش همين سازمان در سال } \\
& \text { 14 • r كلانداده، مجموعهاى از فناورىهاى مختلف مديريت }
\end{aligned}
$$




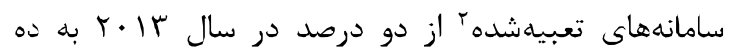

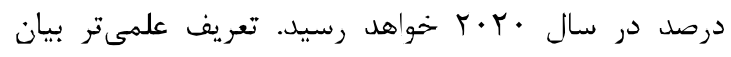

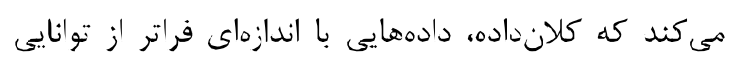

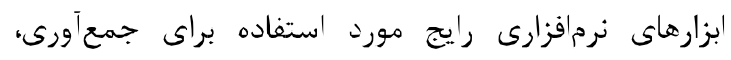
انتخاب و سازماندهى، مديريت، و يردازش دادهها در مدت إنات

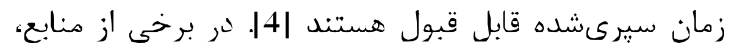

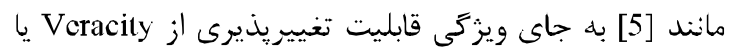

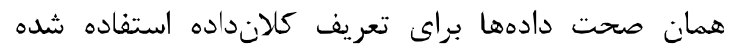

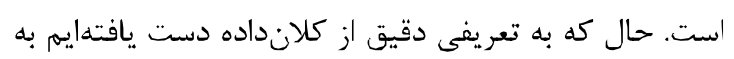

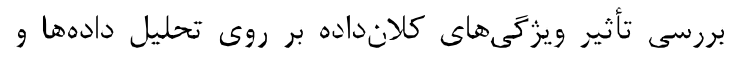
بصرىسازى آنها خواهيم يرداخت. تأثيرات كلانداده بر تحليل اطلاعات را مئودان

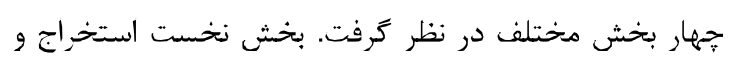

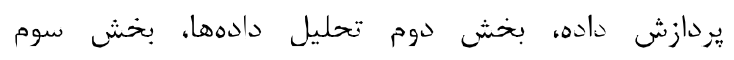
ذخيرهسازى آنها و درنهايت خود بصرىسازى دادههاست.

يردازش داده: در مطالعات مختلف دستهبندىهاى

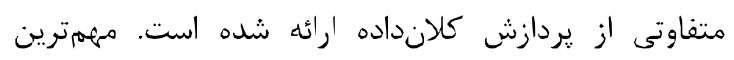

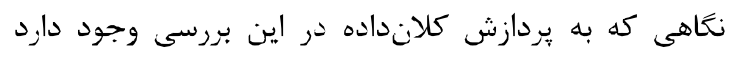

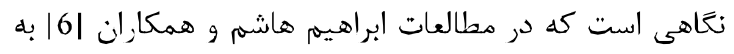

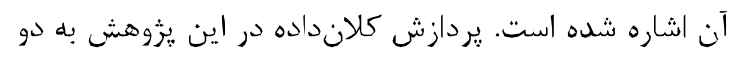

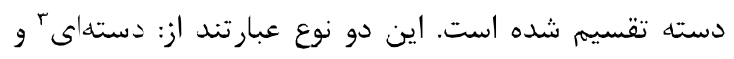

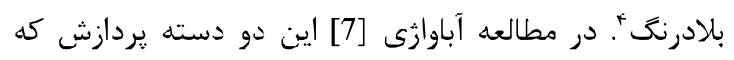

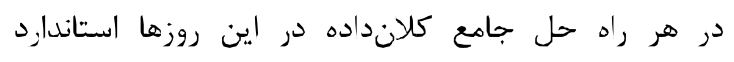

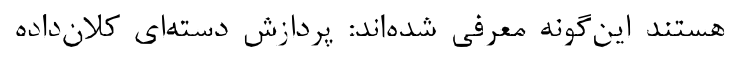

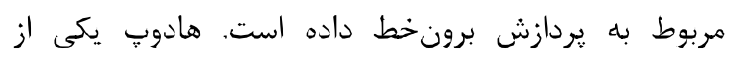

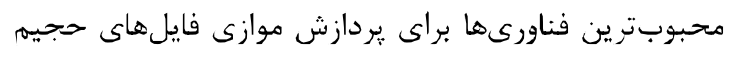

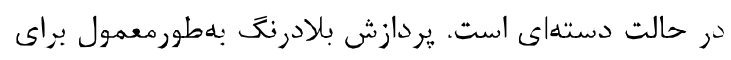

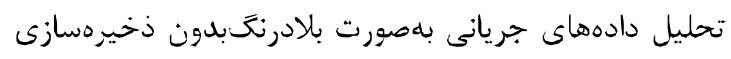

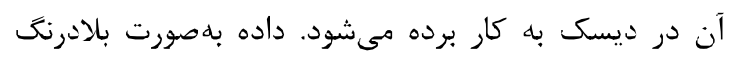

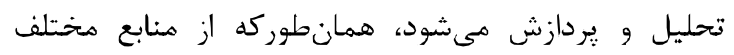

$$
\text { جريان مىيابد، تا يك بينش فورى بلهدست آيد. }
$$

تحليل داده: تحليل دادهها بيش از هر جيزى متأثر از

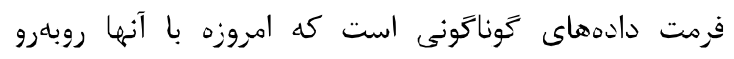

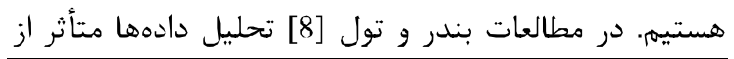

\section{2 embedded \\ ${ }^{3}$ Batch}

${ }^{4}$ Real time
بهراحتى اين امكان را فراهم مى آورد كه بتوانند علاوهبر

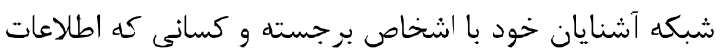

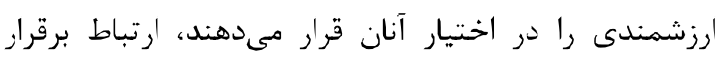

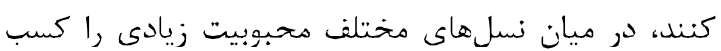

كرده است [2].

در اين يُزوهش تلاش بر آن بوده است كم انواع ابزارها

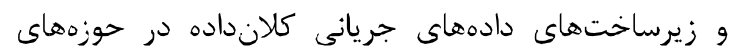

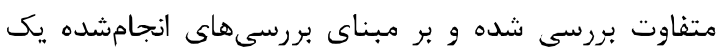

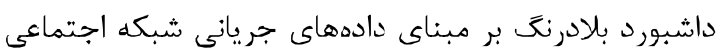

$$
\text { توييتر طراحى شود. }
$$

بلهور كلى مقاله يِش رود دو دو سؤل اساسى را دنبال

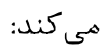

• نحوه طراحى و بيادهسازى يك داشبورد بلادرنگ بر

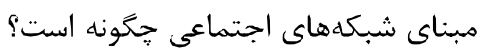

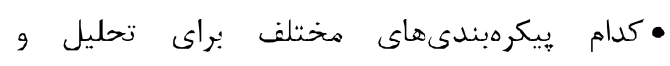
بصرىسازى داشبورد بلادرنخ مناسبتر هستند؟

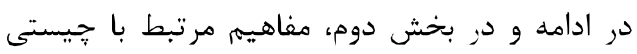

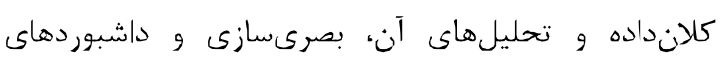

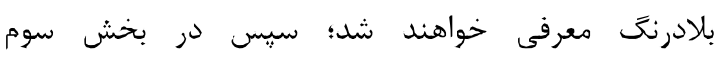

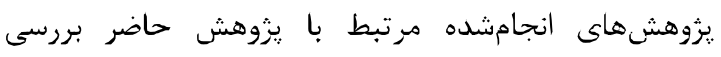

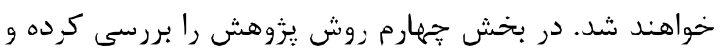

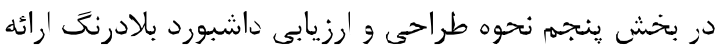

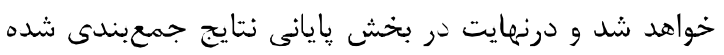

$$
\text { و مورد بحث قرار خواهند كرفت. }
$$

\section{r- مبانى نظرى}

امروزه با توجه به بيشرفت فناورى ولى و زيستن در عصر

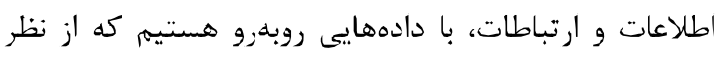

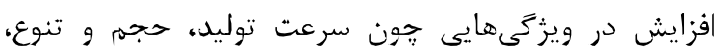

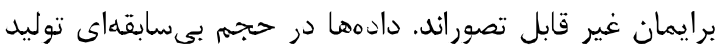

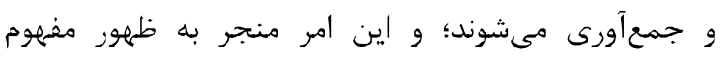

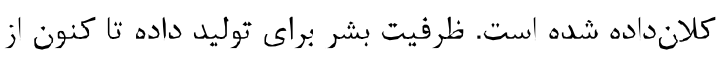

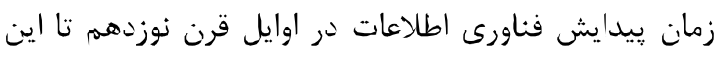

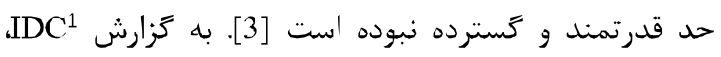

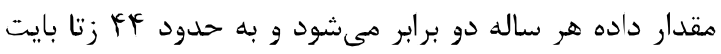

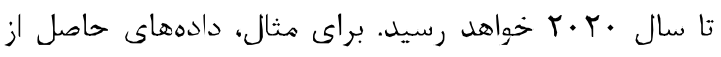

\footnotetext{
${ }^{1}$ International Data Corporation
} 
كليد ارزشى بر هستندات"، مبتنى بر ستون"، هبتنى بر كرافه و و

بصرىسازى: همانطور كه بِيشتر كفتيم، در عصر

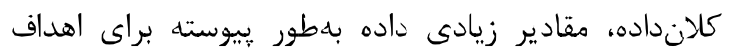

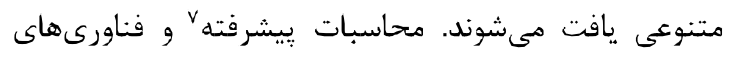

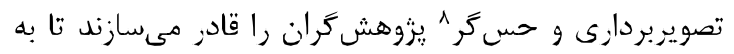
مطالعه بديدهای طبيعى و فيزيكى در دقت بىسابقهاى

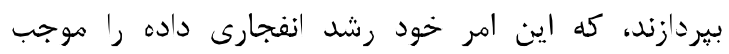
مىشود. بصرىسازى اين حجم دادة روبهرشد جه به شكل

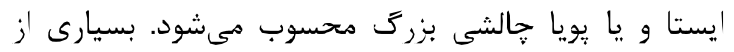
رويكردها و ابزارهاى سنتى بصرىسازى در مقياس بز بزرى

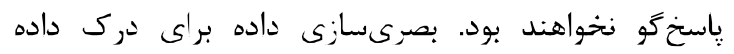

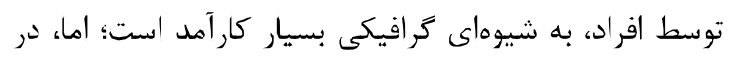

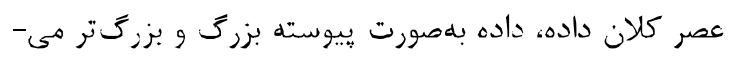

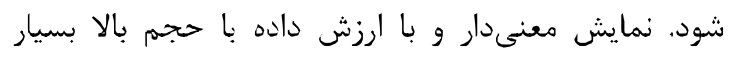

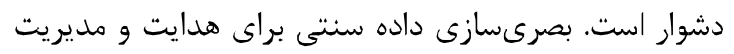

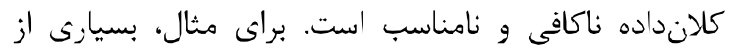
مجموعهدادهها براى جاى كذارى در حافظه بسيار حجيه بوده و شايد در سراسر يك خوشه توزيع شوند [15]. بصرىسازى

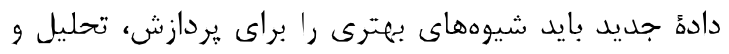
بصرىسازى مقادير بالاى دادهاى بيجيديده ارائه دهد. درهميناواخر، موضوع تحليلهاى بلادرنت دادههاى

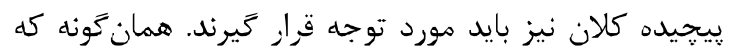

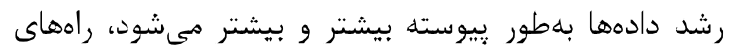

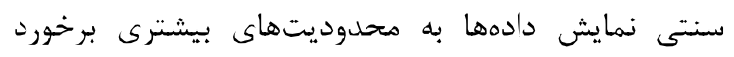

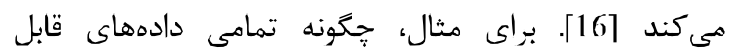

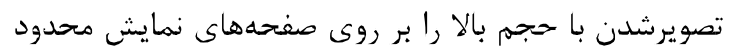
نمايش טاد (بررسى טادههاى با حجم زتا بايت به جاى كيعا

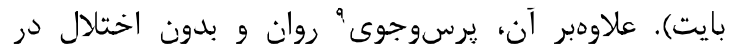

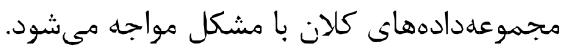
همجنين نمايش دادههاى حجيم بلصورت بلادرنگ

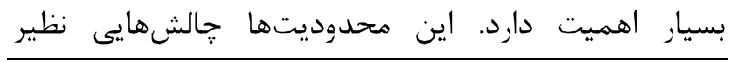

${ }^{3}$ Document-oriented

${ }^{4}$ Column-oriented or wide column

${ }^{5}$ Graph-oriented

${ }^{6}$ Key-value

${ }^{7}$ Advanced computing

${ }^{8}$ sensing

${ }^{9}$ Query
فرمتشان در ردههاى مختلفى تقسيمربندى شدهاند، كه

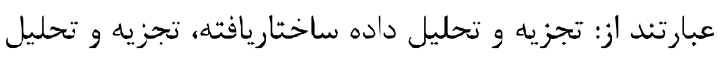

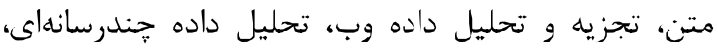
تجزيه و تحليل شبكه و دادههاى موبايل.

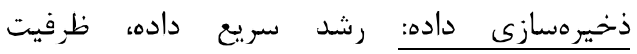

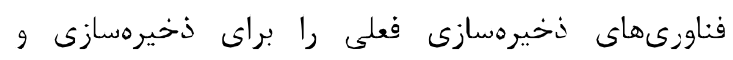

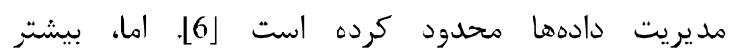
سيستمهاى ذخيرهسازى براى ذخيرهسازى و مديريت كلانداده داراى محدوديت بوده و نامناسب هستند. براى ديري

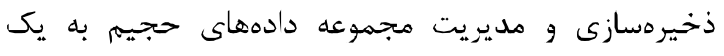
معمارى ذخيرهسازى كه بتواند بهشيوهاى بسيار كاراهد

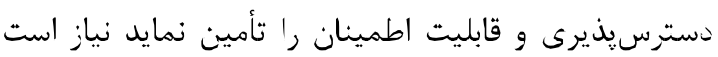
[6]. درنتيجه عصر كلانداده، محدوديتهاى بسيارى مربوط

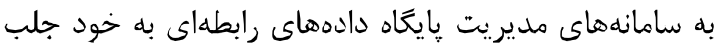

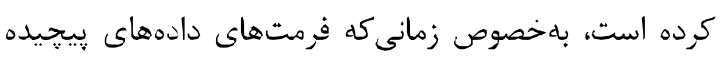

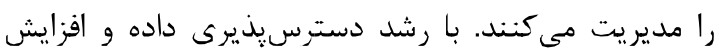

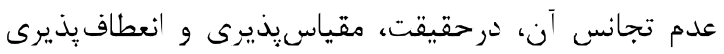

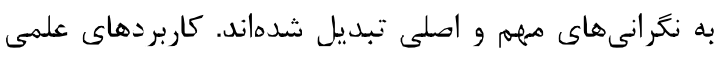
فعلى با مقادير بالاى دادؤ نيمهساختاريافته و غيرساختاريافته از قبيل آرايههاى جندبعدى، ترافها و شبكههاى نامرتب'

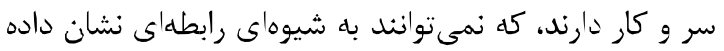
شوند؛ بنابراين، از الزامات اصلى نسل بعدى ثايكاه دادهادها،

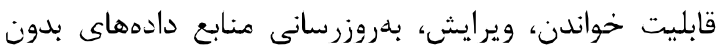

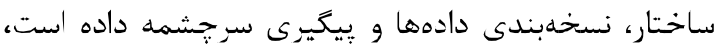

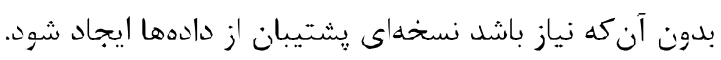

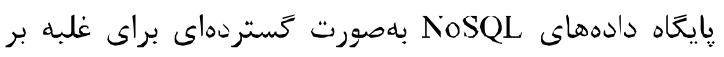

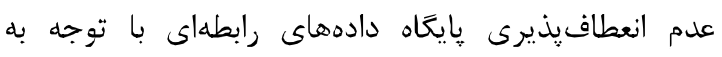

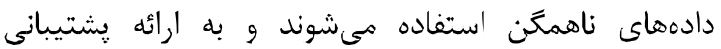
بهبوديافته براى يرسوجوهاى ` توزيعشده و ذخيرة يكيارجها

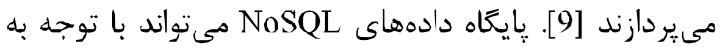
تقسيم بندىهاى ارائهشده در يثوهشهاى تئودوريكا و همكاران 10]]، كتل [11]، هجت و همكاران [12] و ليويت [13] كه هر كدام طرح خاص براى دادة ذخيرهشده تجويز

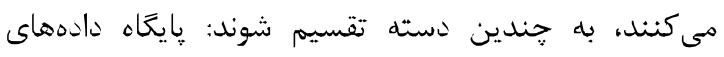

${ }^{1}$ Irregular meshes

${ }^{2}$ Queries 


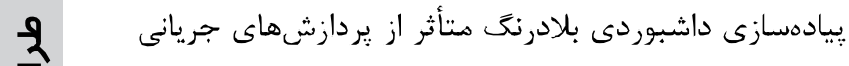

بصرىسازى مى كند، بوده است.

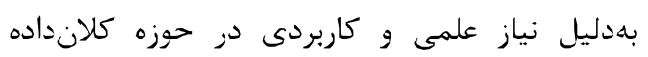

امروزه يُووهشها و مطالعات بسيارى در زمينههاى مختلف دارئل

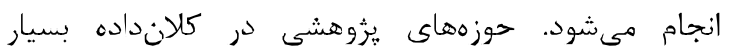
كسترده بوده و هر كدام بلهورت جزئي، بخشى از اين حوز حوزه

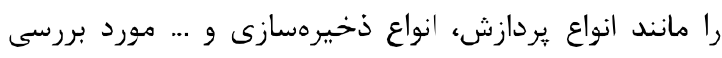

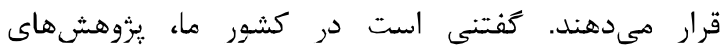
صورتكرفته نسبت به يزوهشىهاى بينالمللى اندك بوده

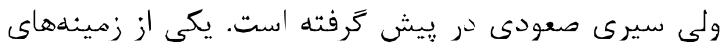

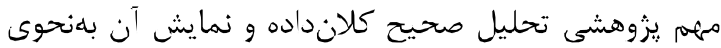
قابل فهم براى كاربران نهايى است. در جدول (1) خلاصهاى

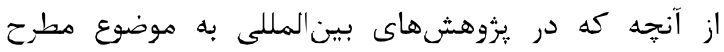

$$
\text { يرداخته است، آورده شده است. }
$$

مقياس يذيرى ادراكى'، مقياس يذيرى بلادرنغ و و مقياسيذيرى تعاملى بّ بهوجود آورده است |3|. وقتى صحبت آنسي از كلانداده است، نحوه و جكَّنتى نمايش آن مىتواند به انتقال اطلاعات كمك كند؛ اما نمايش آن به جيزى فراتر از فقط ظاهرى زيباداشتن نياز دارد. داشبورد كلانداده بايد بلدرستى كار كند، قابليت نمايش ابعاد جندكانه را داشته

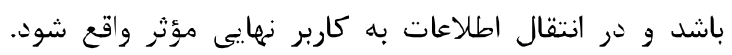
بصرىسازى كلانداده همجنين فرصتهايى براى راههاى

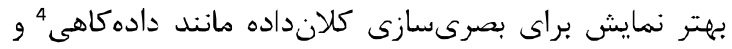
كاهش زمان تأخيره و ... به وجود مى آورد [17].

\section{ץ- مبانى تجربى (يزوهشهاى بيشين)}

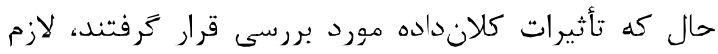

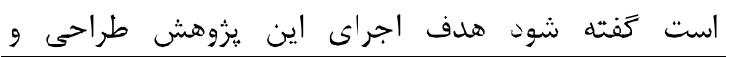

${ }^{1}$ Perceptual scalability

${ }^{2}$ Real time scalability

${ }^{3}$ Interactive scalability

${ }^{4}$ Data reduction

${ }^{5}$ Reducing Latency

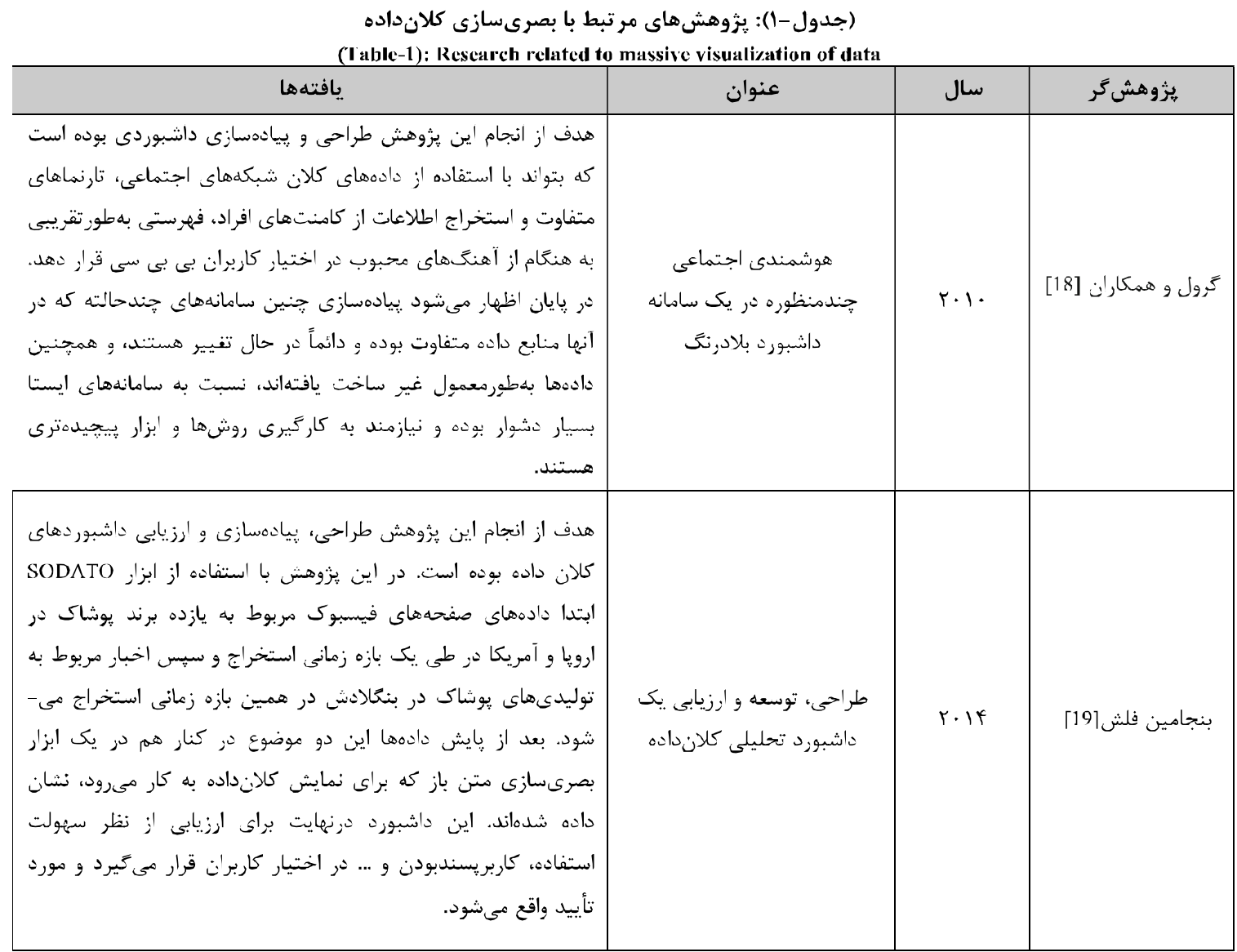




\begin{tabular}{|c|c|c|c|}
\hline يافتهها & عنوان & سال & يخوهش \\
\hline 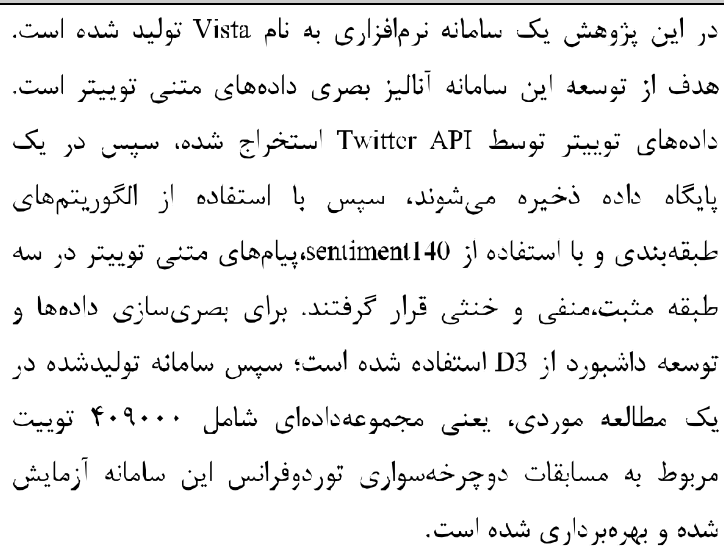 & كُ كزفيه و تحليل بصرى توييتر: & $r \cdot 1 Q$ & هوبر و همكاران [20] \\
\hline 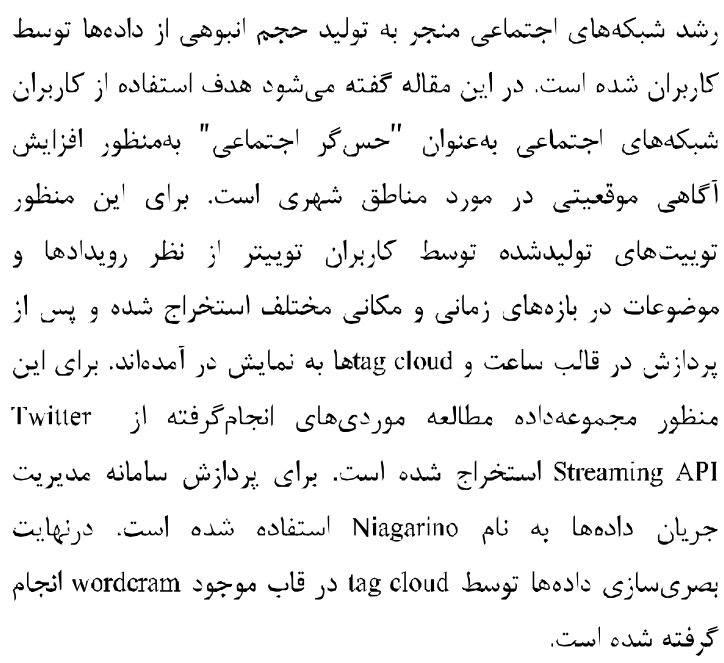 & 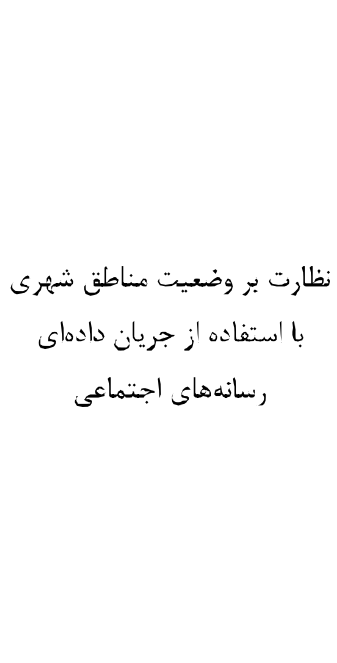 & $r \cdot 10$ & ويلر و همكاران [21] \\
\hline 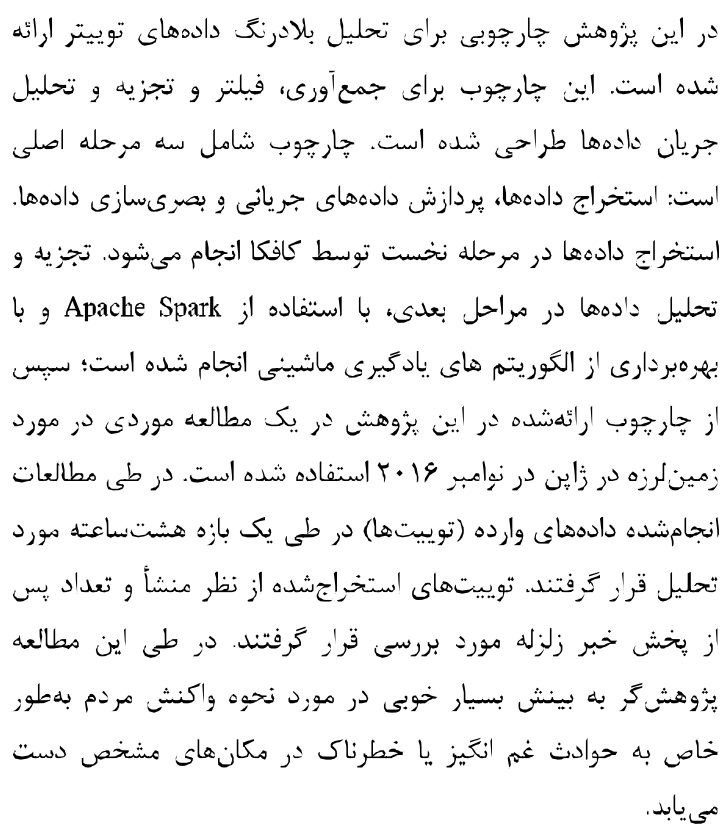 & 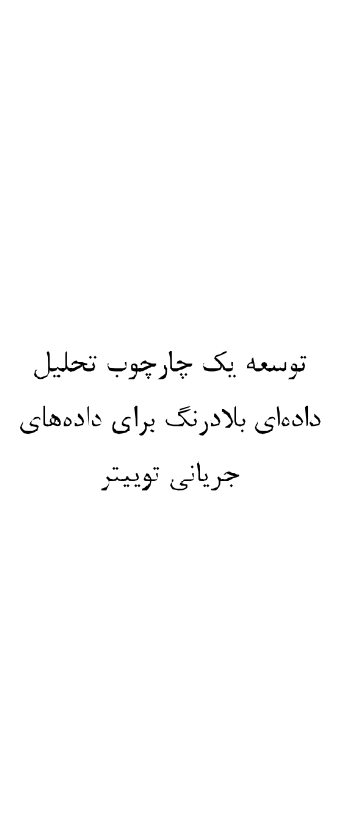 & $r+19$ & بابك يادرنجى اقدم \\
\hline
\end{tabular}


(جدول - Y): اجزا و ويزٔكى هاى ابزارهاى معمارى داشبورد بلادرنت (Table-2): Components and features of real-time dashboard architecture

\begin{tabular}{|c|c|}
\hline ايزار استفاده شده & اجزاى ساخت \\
\hline دانهاى جريانى توييتر & ورونى \\
\hline $\begin{array}{l}\text { Virtualbox } \\
\text { Vagrant }\end{array}$ & مجازى مسازى \\
\hline $\begin{array}{l}\text { Operating System: Lbuntu } \\
\text { (32-bit) } \\
\text { Basc Mcmory: } 2048 \mathrm{MB}\end{array}$ & ماشين مجازى \\
\hline Twitter Streaming API & استخراج داده \\
\hline $\begin{array}{c}\text { آياجى استورم } \\
\text { 0.9.2-Incubating }\end{array}$ & 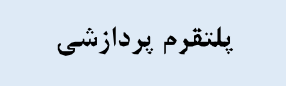 \\
\hline فيلترينگ، تناوب & تكنيكهاى مورد استفاده \\
\hline Java & زبان برنامهنويسى \\
\hline D3.js & ابزار بصرىسازى \\
\hline
\end{tabular}

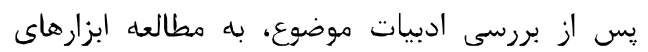
مختلف در اين زمينه برداخته شد. درنهايت از بين ابزارهاي ادرياي

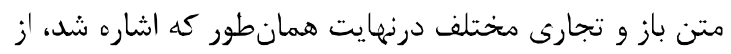

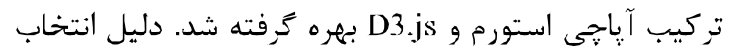

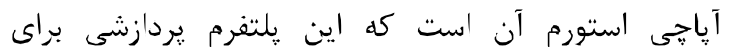

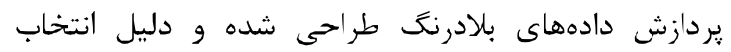

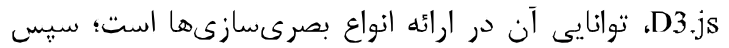

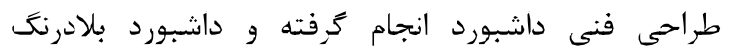

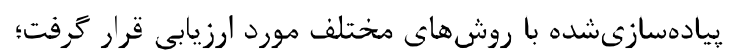
سيس نتايج حاصل از ارزيابىها ارائه و سؤالات يُروهش باسيخ

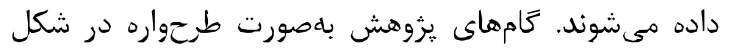

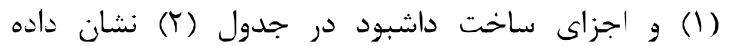

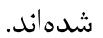

\section{ه- طراحى و ارزيابى \\ طراحى}

براى ساخت يك داشبورد بلادرنگ ابتدا اجزاى مورد نياز

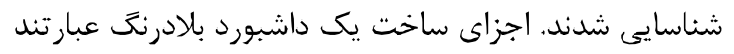

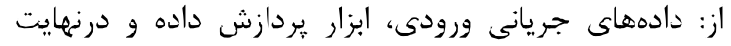

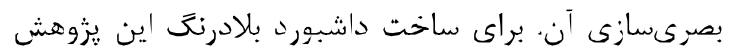

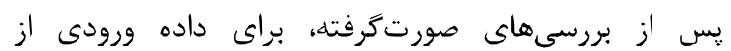

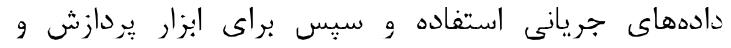

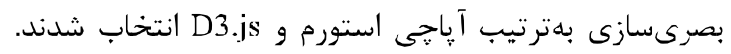
معمارى داشبورد بهصورت طرحواره در شكل (T) نشان داده

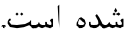

از ميان مطالعات يادشده، دو يزوهشى كه بيش از

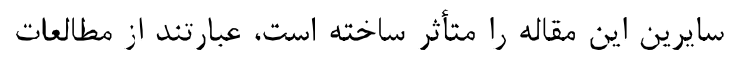

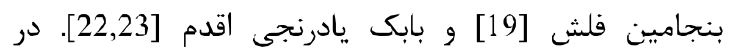

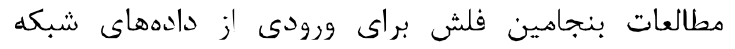

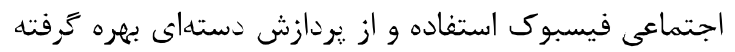

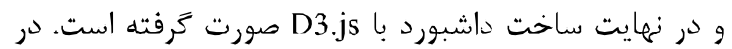

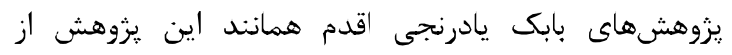

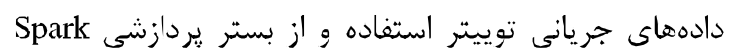
Streaming براى ثبردازش دادهها بهره كرفتيته شده است.

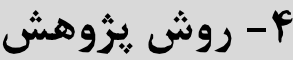

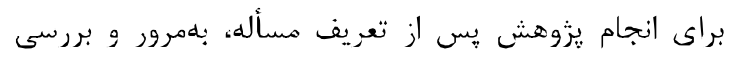

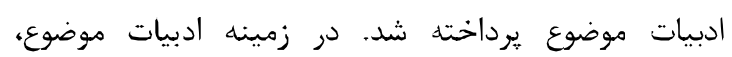

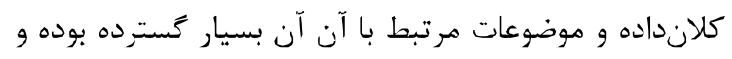

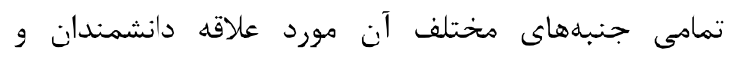

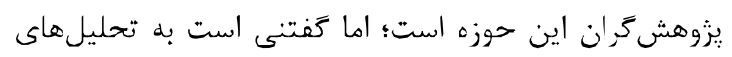

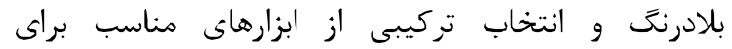

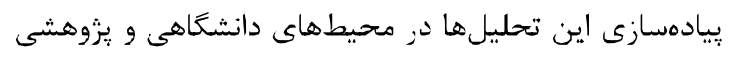

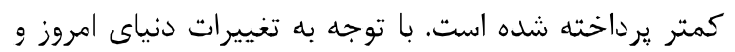

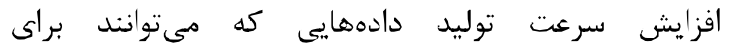

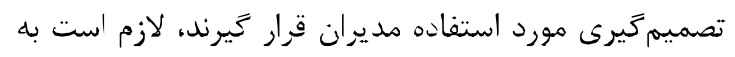

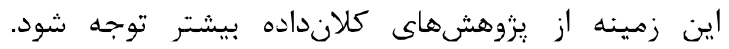

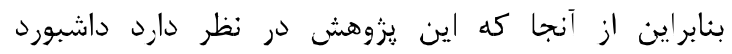

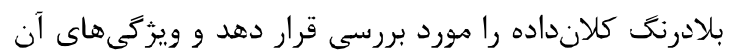
را با داشبوردهاى سنتى مقايسه كرده و درنهايت اقدام به به درائ

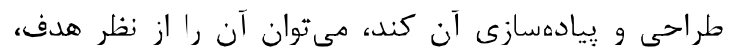

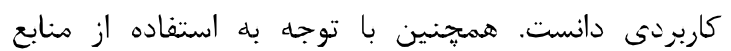
مختلف و دادههاى شبكدهاى اجتماعى، از لحاظ نوع دادهها،

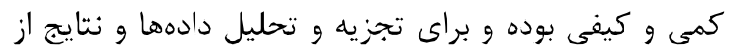
روش آزمايشى بهره جسته است.

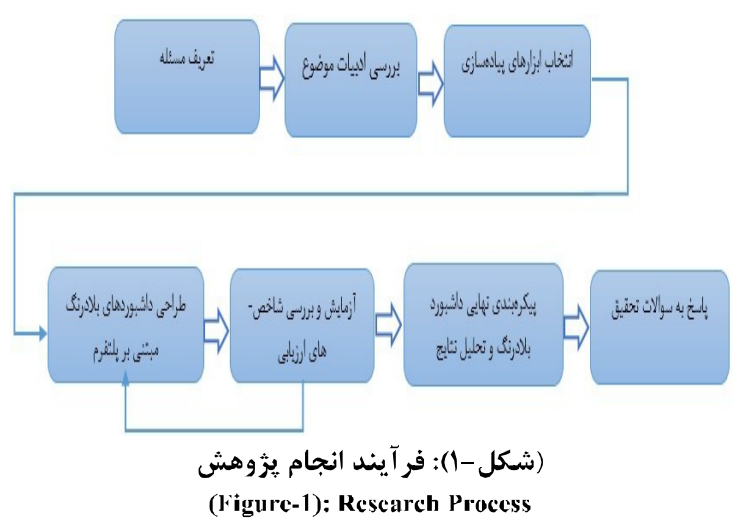




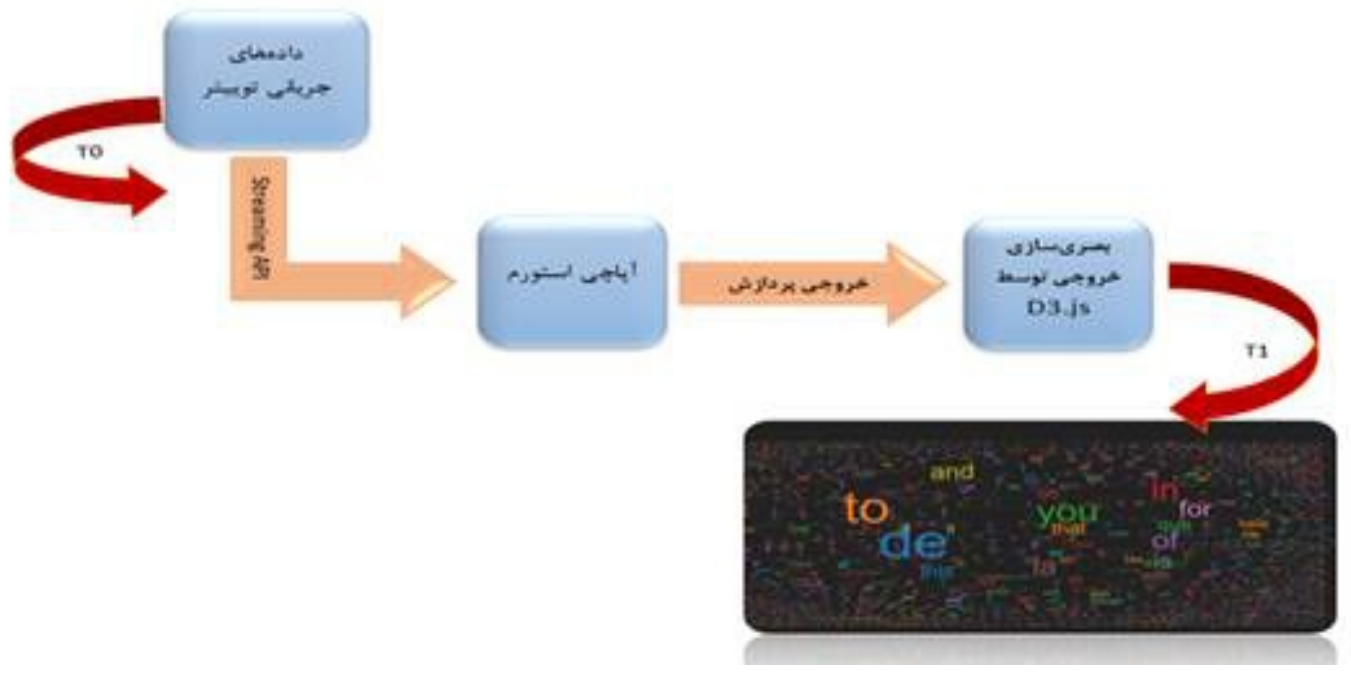

(شكل - (r): معمارى طرحواره داشبورد

(Figure-2): Schematic architecture of the dashboard

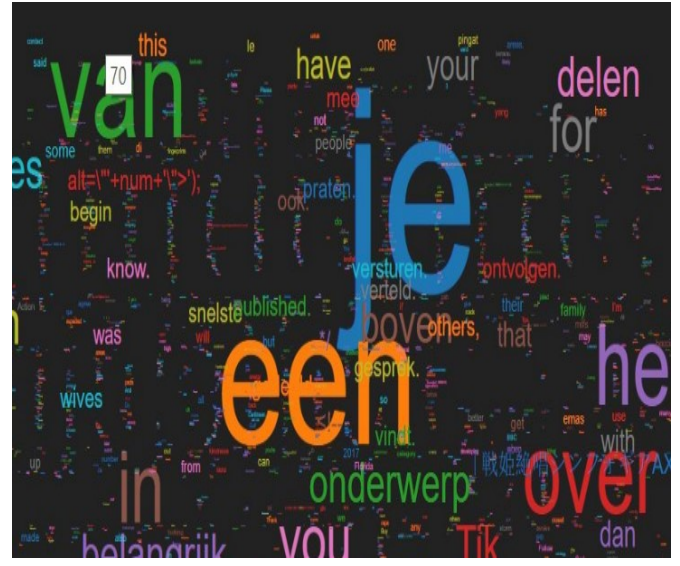

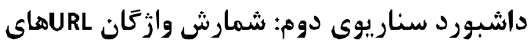

$$
\text { توييتهاي كاربران }
$$

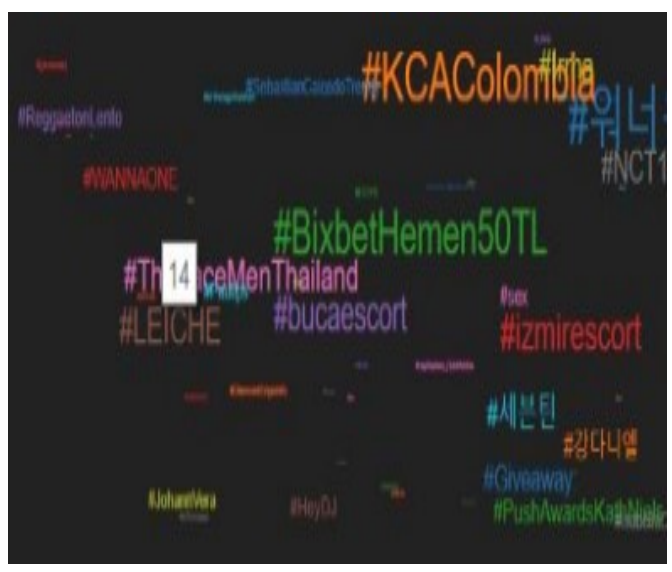

سناريوى سوم: يافتن بيشترين هشتخَها و نمايش آنها با روش ابر وازه
قادههاى جريانى توييتر در زمان T0 توسط

Streaming API

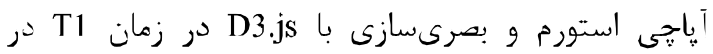
داشبورد نمايش داده مىشوند. براى طراحى محتواى داشبورد از سه سناريو بهره برده مىشود. سناريوى نخست: شمارش وازًّان توييتهاى جريانيافته و

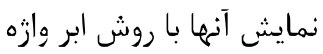

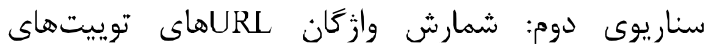

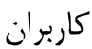
سناريوى سوم: يافتن بيشترين هشتغها و نمايش آنها با روش ابر وازه براى هر كدام از سناريوها خروجى به شكل زير است:

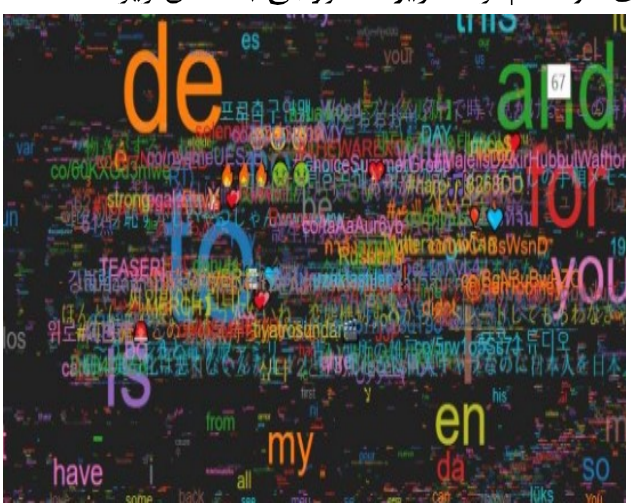

$$
\text { داشبورد سناريوى نخست: شمارش وازگًان توييتهاى }
$$

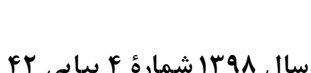




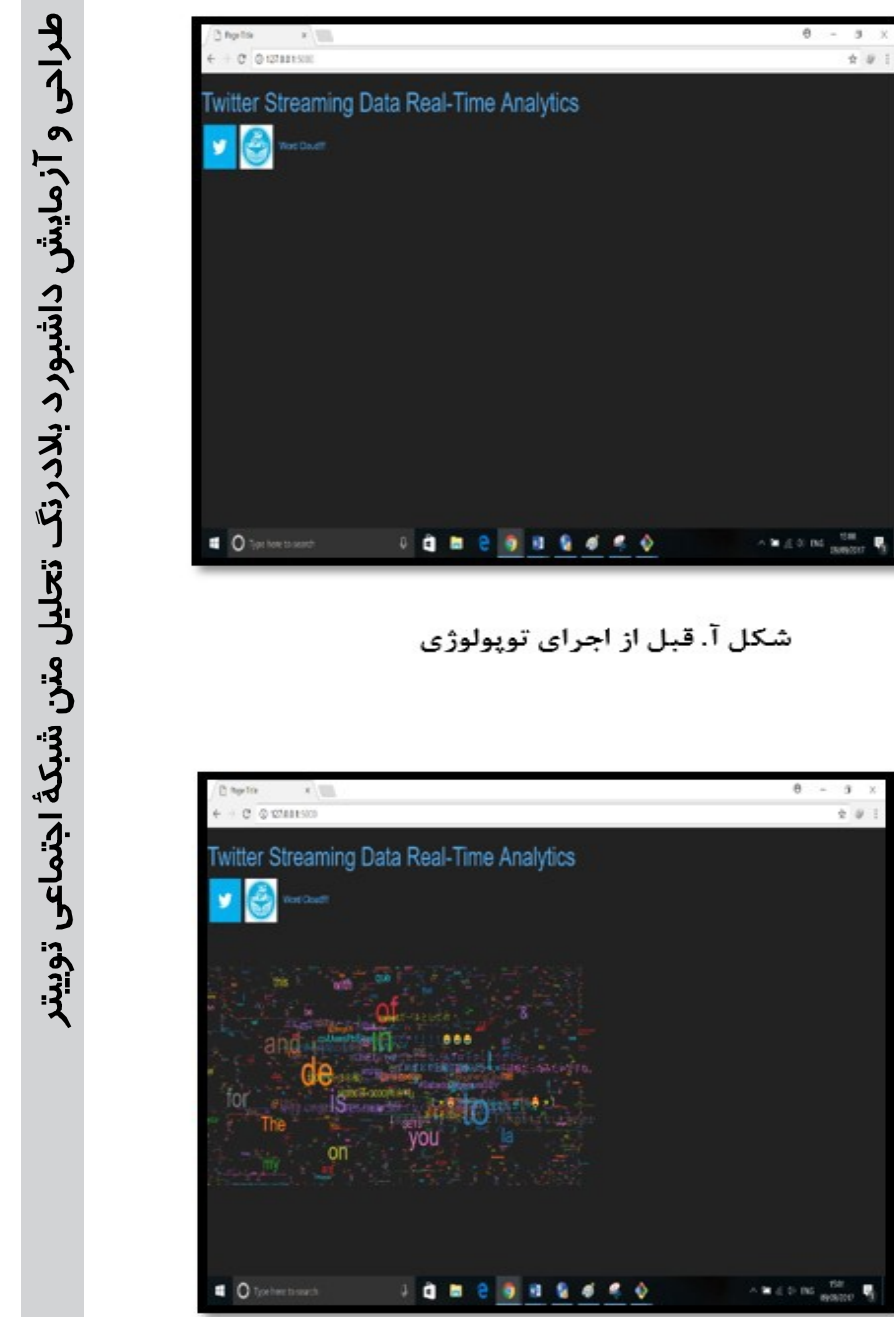

شكل پ. *م ثانيه يس از اجرا

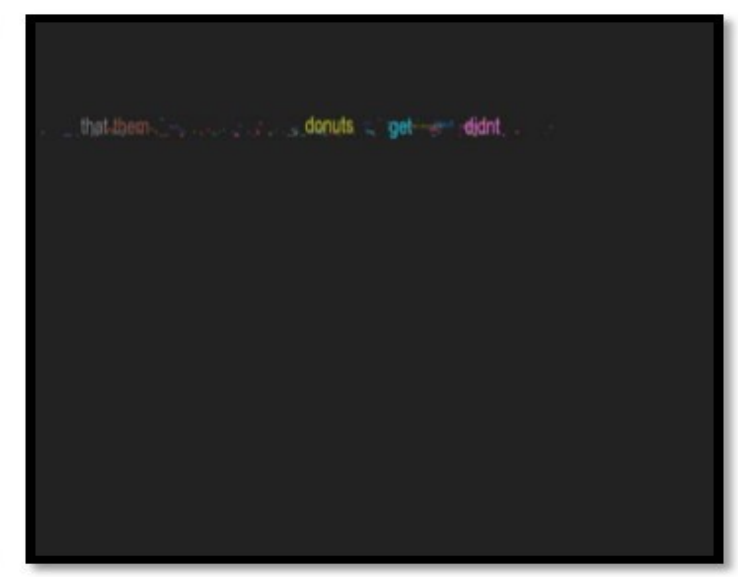

شكل ب. +r ثانيه يس از اجرا

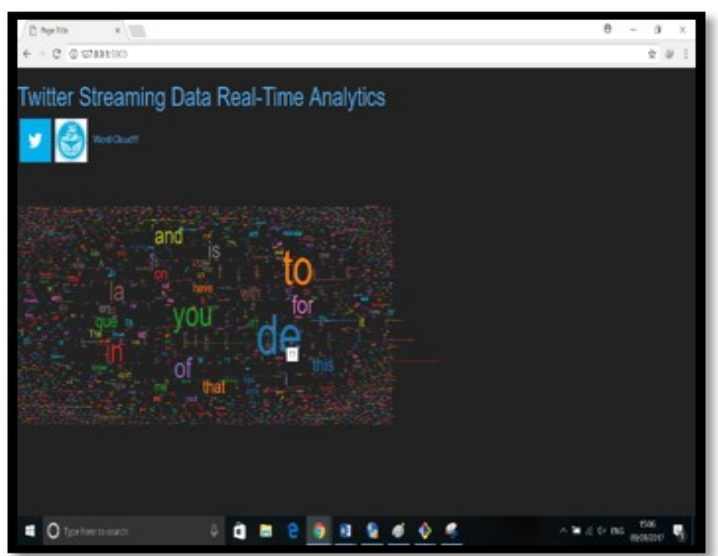

شكل ت. اتمام اجراى تويولورى

(شكل - r): مر احل اجراى بصرىسازى

(Figure-3): Visualization implementation steps

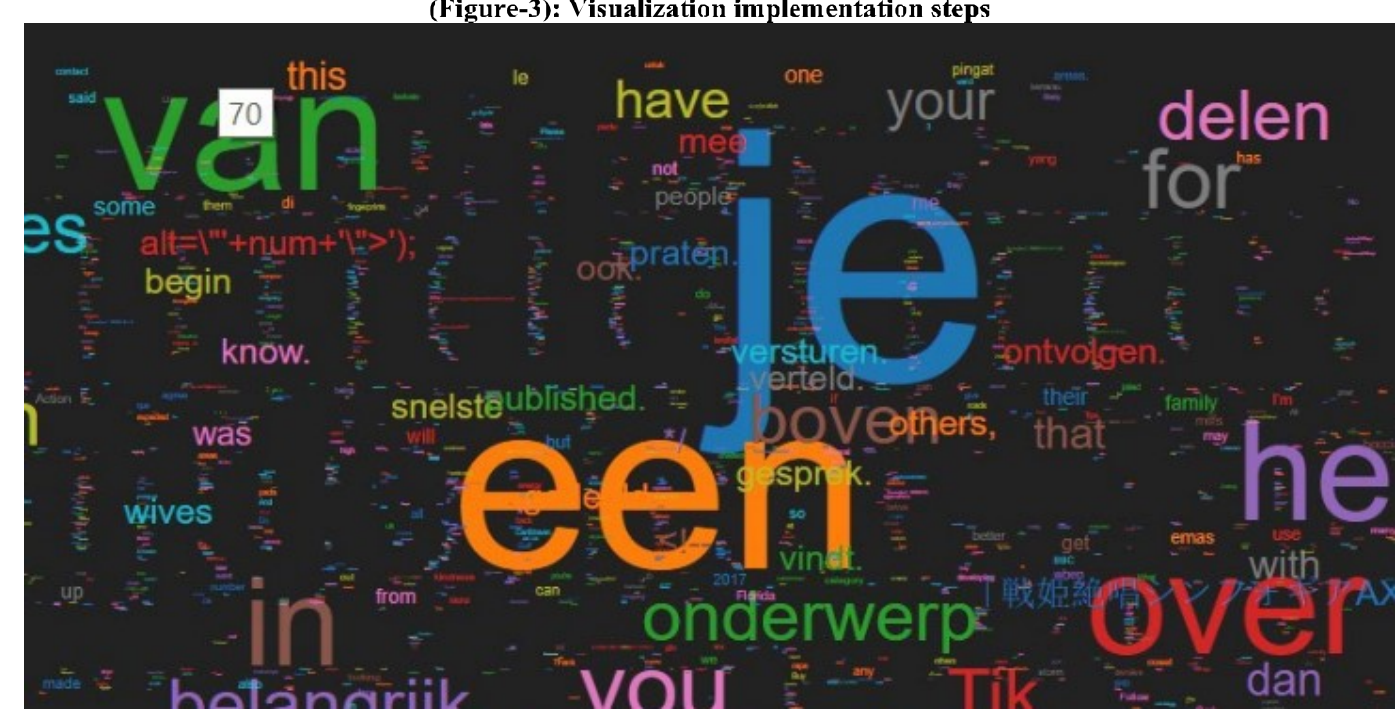

(شكل - \$): نمايى نزديك از داشبورد هارس شدن وازًَان توييتها

(Figure-4): A close view of the parsed Tweets dashboard 
درنتيجه بولت يردازشى ranking براى نمايش بيشترين هشتخها بـ كار گرفته شده است.

در شكلهاى (Y , F F) روند بصرىسازى نشان داده

شده است. همانطور كه در شكل (f) مشخص است، جملات هر توييت به وازگًان سازندهاش شكسته شده و با قرارگرفتن بر روى هر وازه، تعداد آن نمايش داده مىشود.

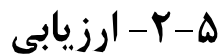

يس از مرور ادبيات مانند مطالعات بابك يادرنجى اقدم [22,23] و كوزدووا [24] اين نتيجه كسب شده كه فرايند ارزيابى داشبوردهاى بلادرنگ بر اساس ميز ان زمان طىشده از توليد محتوا تا دريافت ياسخ انجام مىشود. در نتيجه هدف ارزيابى در اين يزوهش نيز بلادرنگبودن داشبورد طراحىشده تعريف شد كه براى سنجش آن از شاخص

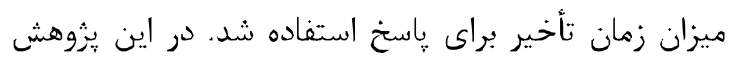

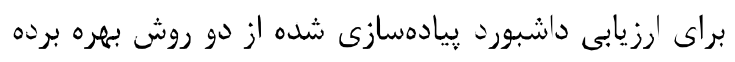

$$
\text { مىشود: }
$$$$
\text { روش 1. سنجش ميزان زمان صرفشده از توليد }
$$

$$
\text { محتوا در توييتر تا نمايش در داشبورد. }
$$

در روش نخست در حساب كاربرى گروه يزوهش محتوايى مشخص توييت مىشود؛ سيس ورونى محيط يردازشى را بهُونهاى فيلتر خواهيم كرد تا تنها اطلاعات

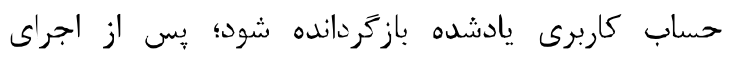

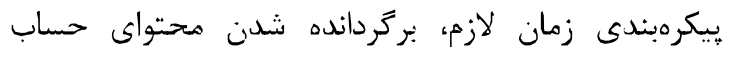

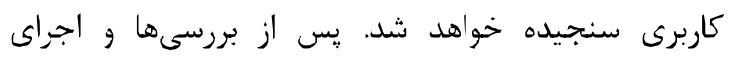

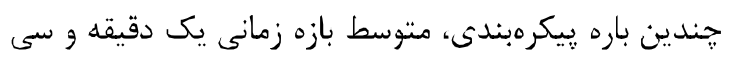
ثانيه بهدست مى آيد. از آنجا كه تأخير در ترافيك شبكانده كاربر و ترافيك سرور را بايد در نظر داشت زمان

$$
\text { بهدستآمده، زمان قابل قبولى خواهد بود. }
$$

روش r. سنجش ميزان زمان صرف شده از اجراى في

$$
\text { بيكر هبندى تا نمايش داده در داشبورد. }
$$

روش دوم براى ارزيابى و بررسى دو فرضيه زير

$$
\text { طراحى شده است. }
$$

يكى از مهمترين بخشهاى ييادهسازى داشبورد بلادرنگ توييتر در اين يثوهش نحوه ييكرهبندى آياجى استورم براى يردازش دادهها است. براى توضيح نحوه

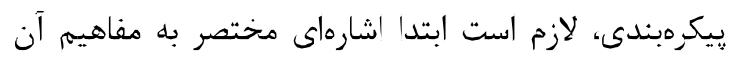

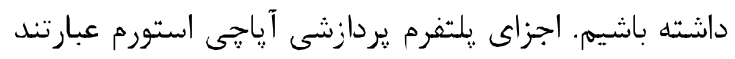

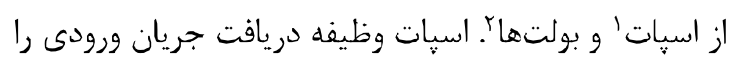
بر عهده داشته و بولتها الكوريتههاى يردازشى را بر روى آن

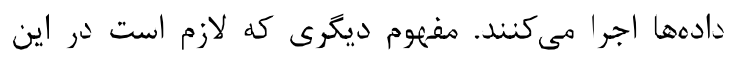

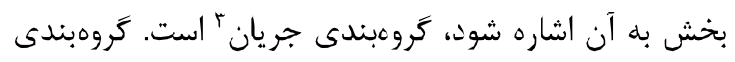

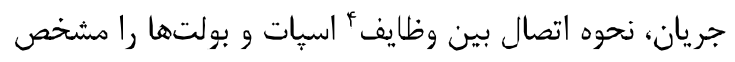
مىسازد. در اين يروهش دو نوع گروهبندى جريان كه به مورد

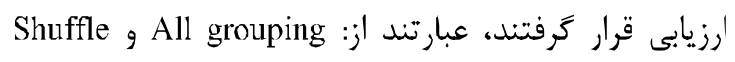
.grouping در All grouping جريان در سراسر تمام وظايف بولتها تكثير مى شود؛ اما در Shuffle grouping، جريان داده به طور تصادفى در سراسر وظايف بولت توزيع شده، توني بلهورىى كه تضمين شده است به هر يك از بولتها تعداد

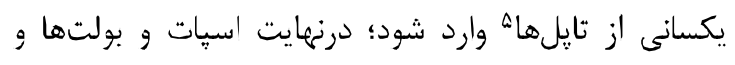
نحوه اتصال آنها را ييكرهبندى مينامند. بلهعبارت ديخر

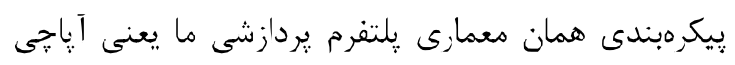
استورم است. در سناريوى نخست و دوم، نمونهاى از دادههاى ديكي توييتر توسط Streaming API استخراج شده و و براى

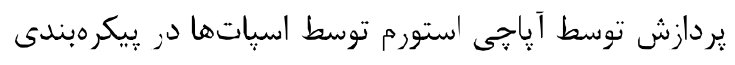

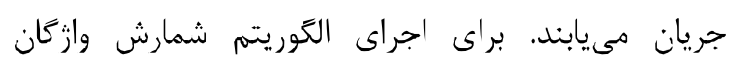
توييتهاى جريانى توسط ايستكاه ابتدايى (Word Count) خوانده شده؛ سيس شمارش تعداد وازَّان خواندهشده در تورئر

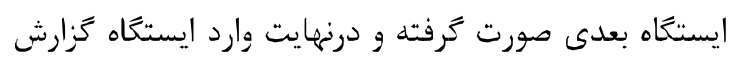
شده و نتايج تحليل نهايى توسط D3.js مصور مىشوند. در سناريوى سوم نيز همانند روش قبل نمونهاى از دادههاى توييتر استخراج شده و براى يردازش توسط آياجى استورم توسط اسياتها در ييكرهبندى جريان مي يابند. تفاوت ييكرهبندى در به كاركيرى بولتهاى متفاوت است. در اين سناريو تنها شمارش هشتخها هدف نهايى نيست و بلكه بركرداندن بالاترين هشتخَهاى (TopN) توييت شده است.

\footnotetext{
${ }^{1}$ Spout

${ }^{2}$ Bolt

${ }^{3}$ Stream grouping

4 Tasks

${ }^{5}$ Tuples
} 


\begin{tabular}{|c|c|c|c|c|c|}
\hline 6 & 30.17 & 6 & 21.72 & 6 & $\mathbf{1 8 . 2 2}$ \\
\hline 7 & 29.17 & 7 & 19.29 & 7 & $\mathbf{1 7 . 9 6}$ \\
\hline 8 & 28.19 & 8 & 18.95 & 8 & $\mathbf{2 1 . 5 6}$ \\
\hline 9 & 26.97 & 9 & 23.46 & 9 & $\mathbf{1 8 . 7 4}$ \\
\hline 10 & 27.32 & $\mathbf{1 0}$ & 22.34 & $\mathbf{1 0}$ & $\mathbf{2 0 . 2 2}$ \\
\hline Avg & $\mathbf{2 7 , 4 6 4}$ & Avg & $\mathbf{2 0 . 6 2 1}$ & Avg & $\mathbf{2 1 . 0 9 7}$ \\
\hline
\end{tabular}

all جدول - ه) : ييكرهبندى با اتصال

(Table-5): Topology with all grouping

\begin{tabular}{|c|c|c|c|c|c|}
\hline $\begin{array}{l}\text { Word } \\
\text { Count }\end{array}$ & Time(s) & $\begin{array}{l}\text { URLs } \\
\text { Parsing }\end{array}$ & Time(s) & TopN & Time(s) \\
\hline 1 & 64.28 & 1 & 25.10 & 1 & 31.26 \\
\hline 2 & 26.51 & 2 & 27.42 & 2 & 32.02 \\
\hline 3 & 33.16 & 3 & 22.85 & 3 & 29.42 \\
\hline 4 & 29.42 & 4 & 24.17 & 4 & 32.23 \\
\hline 5 & 26.44 & 5 & 24.32 & 5 & 35.12 \\
\hline 6 & 33.03 & 6 & 26.14 & 6 & 29.53 \\
\hline 7 & 31.22 & 7 & 27.13 & 7 & 27.76 \\
\hline 8 & 27.09 & 8 & 25.67 & 8 & 28.08 \\
\hline 9 & 26.46 & 9 & 24.26 & 9 & 31.09 \\
\hline 10 & 31.15 & 10 & 25.02 & 10 & 27.44 \\
\hline Avg & 32.848 & Avg & 25.208 & Avg & 30.405 \\
\hline
\end{tabular}

بِ إز استخراج نتايج بالا، اطلاعات بهدستآمده را با آزمون فرض آمارى T در نرمافزار SPSS مورن تحليل قرار

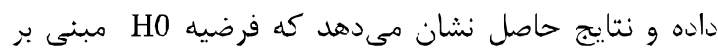

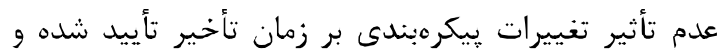

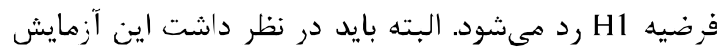

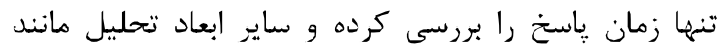

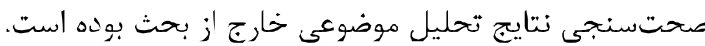

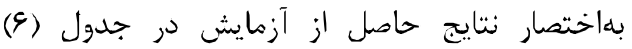

مدهاند.

(جدول - (צ): خلاصد نتايج حاصل از ارزيابى

(Table-6): Summary of the results of the evaluation

\begin{tabular}{|c|c|c|}
\hline \multicolumn{2}{|r|}{ آزمايش نخست } & آزمايش دوم \\
\hline تشريح آزمايش & 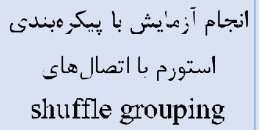 & 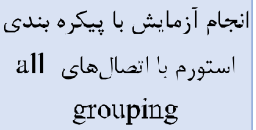 \\
\hline شاخص ارزيابى & زمان تاخير 'رزيابى & زمان تاخير ارزيابى \\
\hline عوامل ثابت & 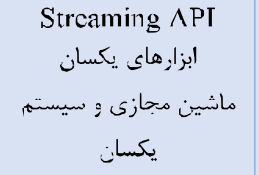 & 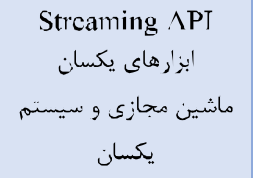 \\
\hline عوامل متغير & $\begin{array}{l}\text { يِكرمبندى استورم با } \\
\text { shuffle grouping }\end{array}$ & 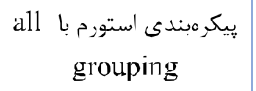 \\
\hline كتنتير هاى غيرقابل (تصادفى) & ترافيك سرور توييتر & ترافيك سرور توييتر \\
\hline نتايج & $\begin{array}{c}\operatorname{Avg}(\text { Latency })= \\
23.06\end{array}$ & $\begin{array}{c}\operatorname{Avg}(\text { Latency })= \\
29.487\end{array}$ \\
\hline
\end{tabular}

تنغيرات بيكرهبندى آپاجى استورم بر زمان تأخير مؤثر :H0

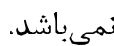
م1 H1: تغييرات بيكرهبندى آياجى استورم بر زمان ثأخير مؤثر

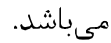

براى تحقق روش دوم و بررسى فرضيههاى بالا از

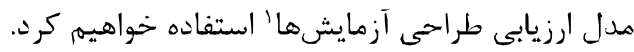

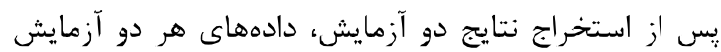

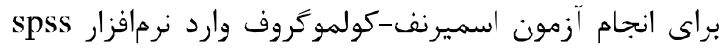
statistics شده و با انجام تحليل درمى يابيم، توزيع نمونه

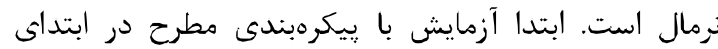

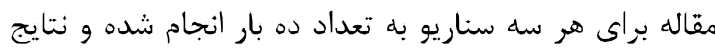

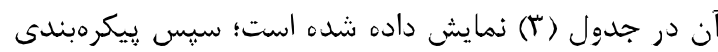

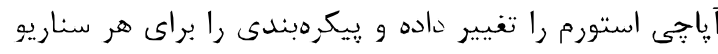

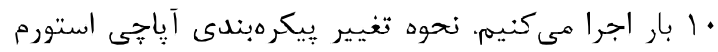
در شكل (a) آمده است.

(جدول-r): آزمون اسميرنف -كولموكروف

(Table-3): Smirvov-Kolmogorov test

\begin{tabular}{|c|c|c|c|}
\hline & & VAR00001 & VAR00002 \\
\hline \multicolumn{2}{|l|}{$\mathrm{N}$} & 30 & 30 \\
\hline \multirow{2}{*}{$\begin{array}{c}\text { Normal } \\
\text { Parameters }^{\mathrm{a}, \mathrm{b}}\end{array}$} & Mcan & 23.0573 & 30.74 \\
\hline & $\begin{array}{c}\text { Std. } \\
\text { Deviation }\end{array}$ & 3.80498 & 6.832 \\
\hline \multirow{3}{*}{$\begin{array}{c}\text { Most Extreme } \\
\text { Differences }\end{array}$} & Absolute & .155 & .295 \\
\hline & Positive & .155 & .295 \\
\hline & Negative & -.115 & -.231 \\
\hline \multicolumn{2}{|c|}{ Test Statistic } & .155 & .295 \\
\hline \multicolumn{2}{|c|}{ Asymp. Sig. (2-tailed) } & $.063^{\mathrm{c}}$ & $.000^{\mathrm{c}}$ \\
\hline
\end{tabular}

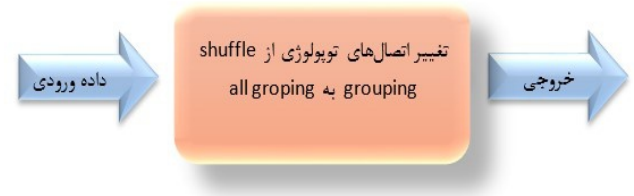

(شكل -ه): تغيير در بيكر دبندى آياجى استورم

(Figure-5): Changes in Apache Storm configuration

نتايج حاصل بعد از اجراى پييكرهبندى با بيكرهبندى تغيير يافته نيز در جدول (ه) آمده است.

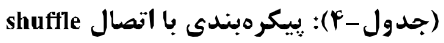
(Table-4): Topology with shuffle grouping

\begin{tabular}{|c|c|c|c|c|c|}
\hline $\begin{array}{l}\text { Word } \\
\text { Count }\end{array}$ & Time(s) & $\begin{array}{c}\text { URLs } \\
\text { Parsing }\end{array}$ & Time(s) & TopN & Time(s) \\
\hline 1 & 27.24 & 1 & 18.87 & 1 & 21.76 \\
\hline 2 & 29.36 & 2 & 21.27 & 2 & 20.89 \\
\hline 3 & 23.71 & 3 & 19.15 & 3 & 22.43 \\
\hline 4 & 25.97 & 4 & 18.63 & 4 & 27.36 \\
\hline 5 & 26.44 & 5 & 22.53 & 5 & 21.83 \\
\hline
\end{tabular}

${ }^{1}$ Design of experiments (DoE) 
توييتر براى نمايش محتواى داشبورد استفاده شده است؛

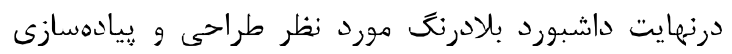

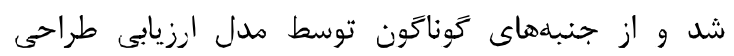

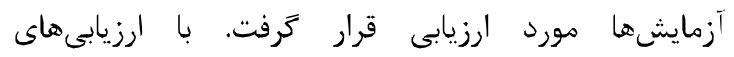

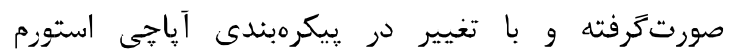

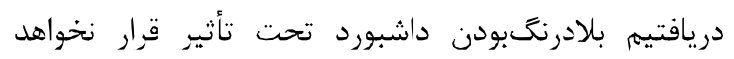

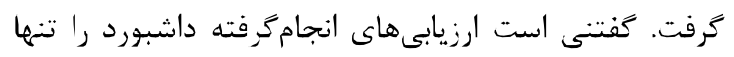

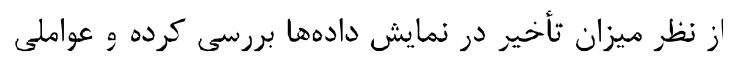

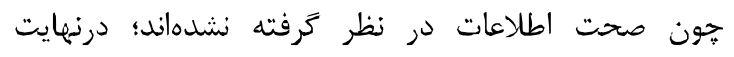

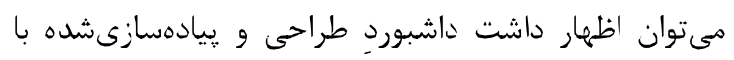

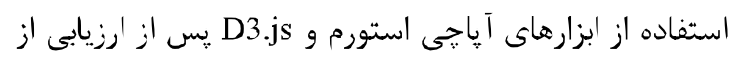

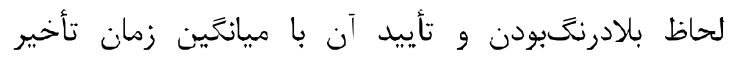

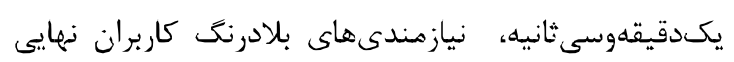
آن را مىتواند تأمين كند.

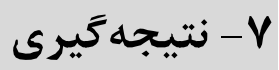

در اين يُوهش با استفاده از ابزارى كه امروزه براى يياده

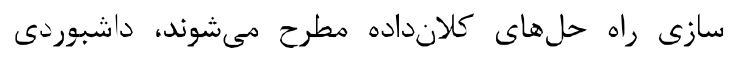

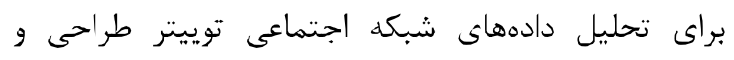

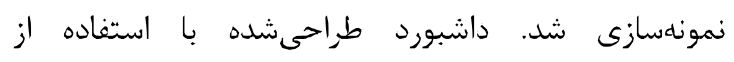

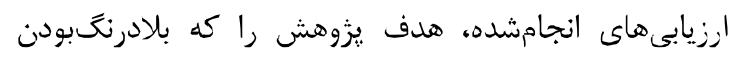

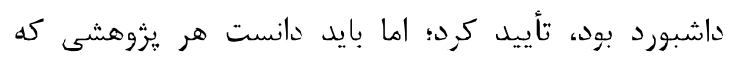

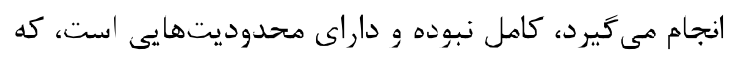

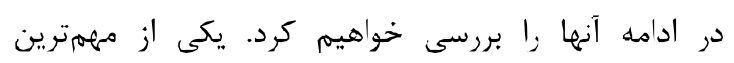

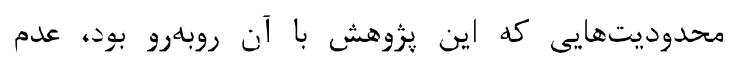

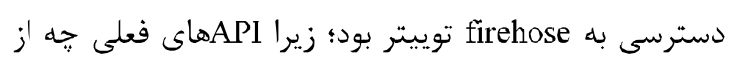

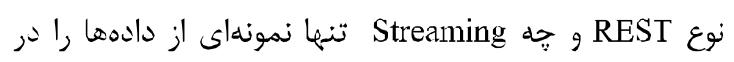
اختيار توسعدهندكان قرار مى نهد. كفتنى است، دسترسى

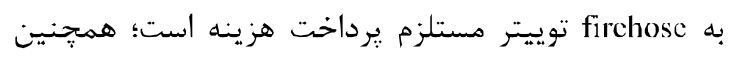

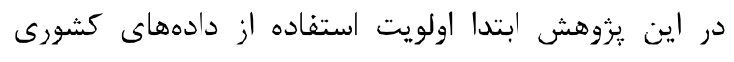

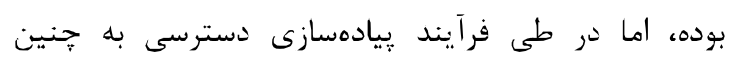

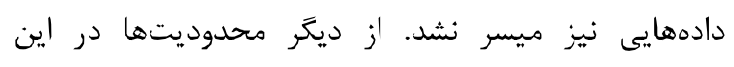

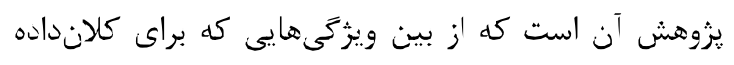

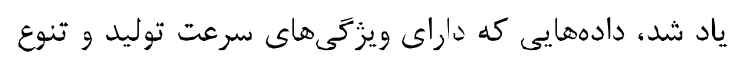

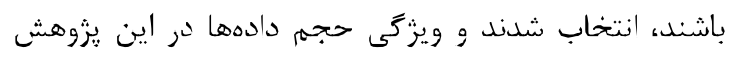

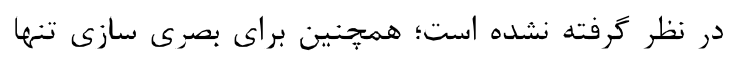

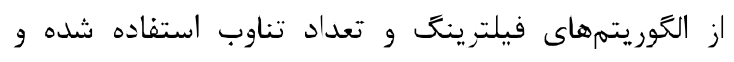

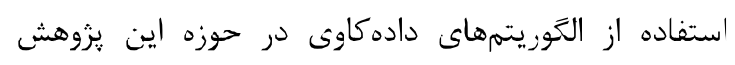

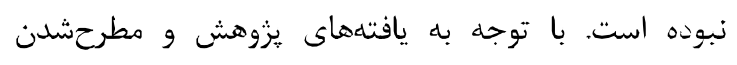

توجه به اين نكته حائز اهميت است كه براى

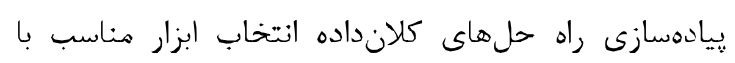

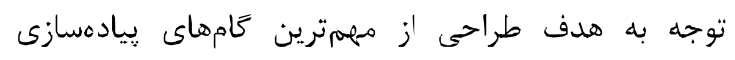

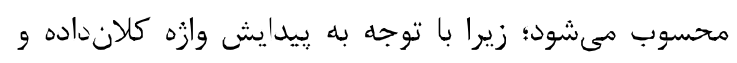

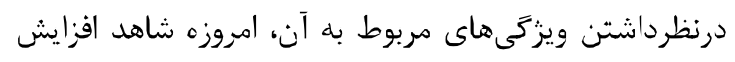

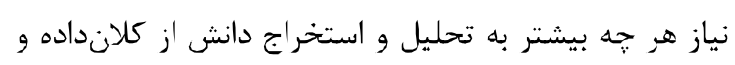

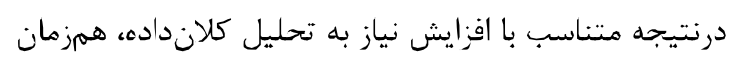

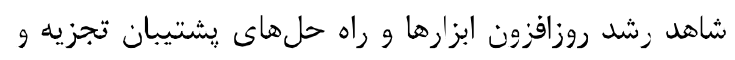

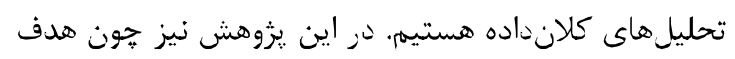

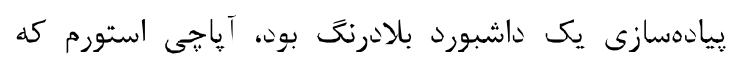

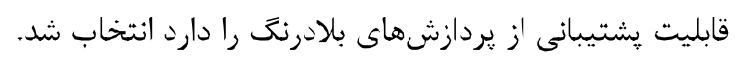

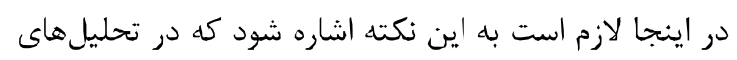

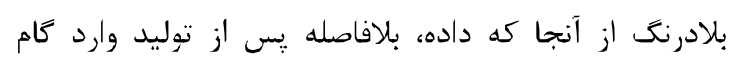

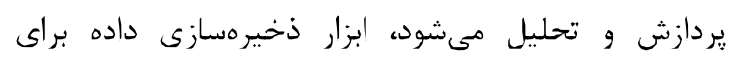

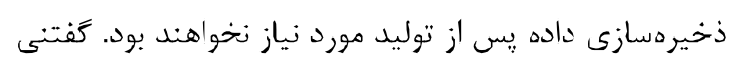

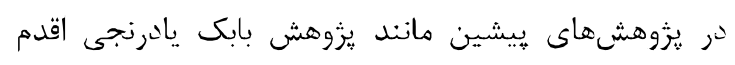

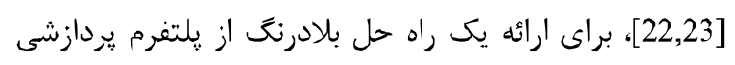
Spark Streaming

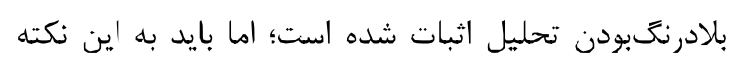

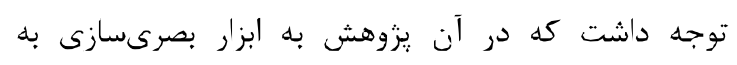

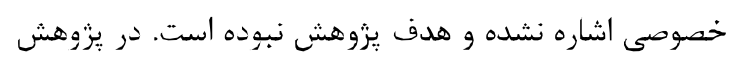

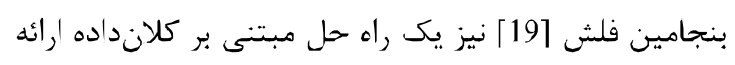

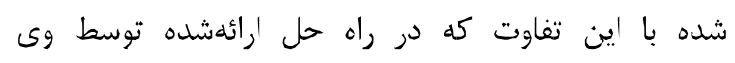

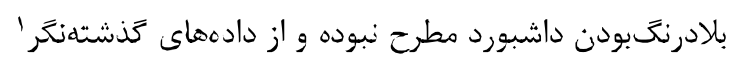
بهره كرفته شده است.

\section{9- مباحثه}

نكته ديكرى كه در اين بخش كَفتنى است، آن است كه از

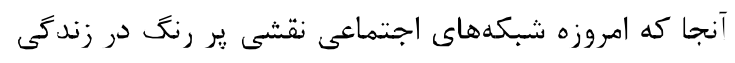

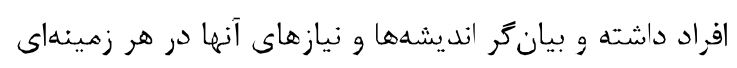

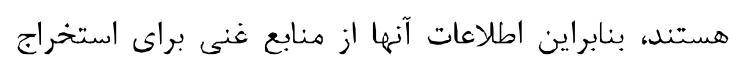

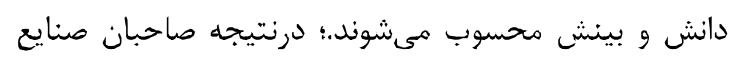

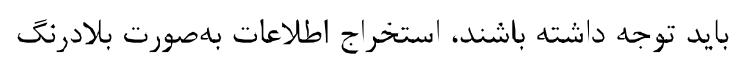

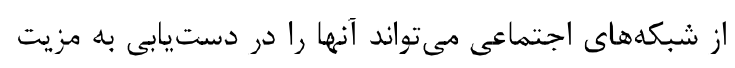

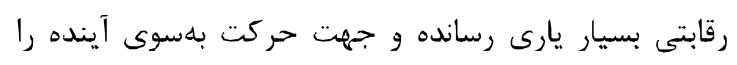

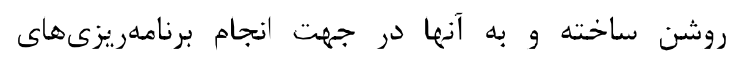

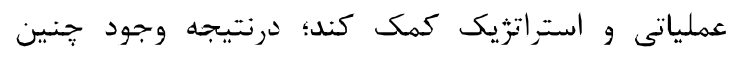

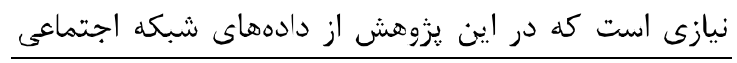

${ }^{1}$ Archived data 
[5] L.Zhang, A.Stoffel, M.Behrisch, S. Mittelstadt, T. Schreck, R.Pompl, S.Weber, H.Last, D.Keim, "Visual analytics for the big data era-A comparative review of state-of-the-art commercial systems", In Visual Analytics Science and Technology (VAST), IEEE, 2012.

[6] I. Hashem, I.Yaqoob, N. Anuar, S.Mokhtar, A.Gani, K.Khan, "The rise of "big data" on cloud computing: Review and open research issues", Information Systems, 47: 98-115, 2015.

[7] J.Abawajy, "Comprehensive analysis of big data variety landscape", International journal of parallel, emergent and distributed systems, vol.30 (1): pp.5-14, 2015.

[8] M. R.Bendre, V. R.Thool, "Analytics, challenges and applications in big data environment: a survey", Journal of Management Analytics, vol. 3(3), pp.206-239, 2016.

[9] B.Hu, "A Key-Value Based Application Platform for Enterprise Big Data", in IEEE International Congress on Big Data (BigData Congress), 2014.

[10] B. G.Tudorica, C.Bucur, "A comparison between several NoSQL databases with comments and notes", In Roedunet International Conference (RoEduNet), 2011, 10th, pp. 1-5.

[11] R.Cattell, "Scalable SQL and NoSQL data stores," Acm Sigmod Record, 39(4), pp. 12-27, 2011 .

[12] R. Hecht, S.Jablonski, "NoSQL evaluation: A use case oriented survey," In Cloud and Service Computing (CSC), 2011 International Conference on 2011, 2011,pp. 336-341.

[13] N.Leavitt, "Will NoSQL databases live up to their promise?" Computer, 43(2), 2010.

[14] A.Corbellini, C.Mateos, A.Zunino, D.Godoy, S.Schiaffino, "Persisting big-data: The NoSQL landscape," Information Systems, vol.63, pp. 123,2017

|15| W.Ding, G.Marchionini, "A comparative study of web search service performance," In Proceedings of the ASIST Annual Meeting, Vol. 33, pp. 136-140, Learned Information, 1996.

[16] X.Jin, B.W. Wah, X.Cheng, Y.Wang, "Significance and challenges of big data research," Big Data Research, vol. 2(2), pp. 5964, 2015.

「17] R.Agrawal, A.Kadadi, X.Dai, \& F.Andres, "Challenges and opportunities with big data visualization." In Procecdings of the 7th International Conference on Management of computational and collective intElligence in Digital EcoSystems ,pp. 169-173, ACM, 2015.

$$
\begin{aligned}
& \text { محدوديتها، ريشنهادهاى كاربردى براى طراحى و يياده } \\
& \text { سازى موفق داشبورد بلادرنت عبارتند از: انتخاب دقيق هدف } \\
& \text { طراحى سامانه، طراحى صحيح معمارى سامانه بر مبناى } \\
& \text { هدف، بررسى دادههاى ورودى مورد نياز سامانه و اطمينان از } \\
& \text { حصول دستيابى به دادهها، توجه به نوع پردازش مورد نياز }
\end{aligned}
$$

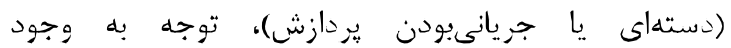

$$
\begin{aligned}
& \text { زيرساختهاى مناسب براى ييادهسازى سامانه؛ درنهايت }
\end{aligned}
$$

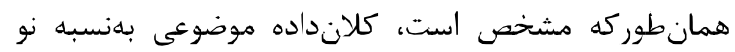

$$
\begin{aligned}
& \text { بهخصوص براى كثنور ما بوده است. در ميان يثوهش گركان } \\
& \text { داخلى بهدليل محدوديتهاى زيرساختى و دادهاى كَفتهشده، }
\end{aligned}
$$

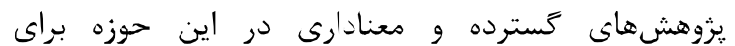

$$
\begin{aligned}
& \text { سازمانهاى ايرانى صورت نكرفته است. بنابراين بهنظر }
\end{aligned}
$$

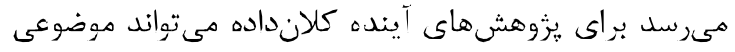

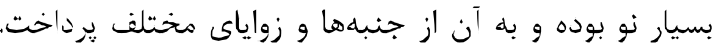

$$
\begin{aligned}
& \text { در انتها مىتوان براى يزوهشهاى آينده موضوعاتى مانيد: }
\end{aligned}
$$

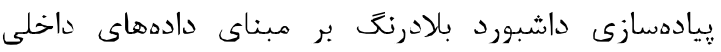

$$
\begin{aligned}
& \text { (دادمهاى سازمانهاى تجارى، تراكنشهاى بانكىى و ...)، }
\end{aligned}
$$

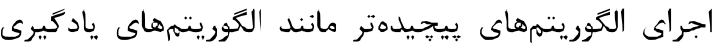

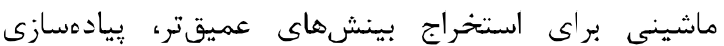

$$
\begin{aligned}
& \text { داشبورد بلادرنت با استفاده از ساير ابزارهاى كلانداده }
\end{aligned}
$$

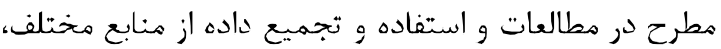

$$
\begin{aligned}
& \text { | إ بيشنهاد كرد. }
\end{aligned}
$$

\section{8-References مراجع - مراجع}

[1] لوشين، ديويد، تحليلهانى كلانداده؛ نقشه راه راه

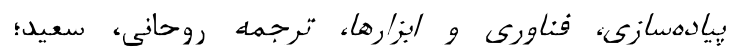

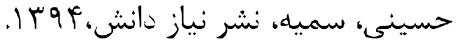

[1] D. Loshin, Big Data Analytics, From Strategic Planning to Enterprise Integration With Tools, Techniques, NoSQL, and Graph, translate by Rouhani, Saced; IIosseini, Somaych, 1394. Big data analysis; roadmap for implementation; technology and tools.

[2] T. Kumamoto, H. Wada, T.Suzuki, "Proposal of a system for visualizing temporal changes in impressions from tweets", International Journal of Pervasive Computing and Communications, Vol. 11, Iss .2, pp. 193 211, 2015.

[3] X.Wu, X.Zhu, G.Wu, W.Ding, "Data mining with big data." IEEE transactions on knowledge and data engineering, vol.26(1), pp. 97-107, 2014.

[4] C.Snijders, U.Matzat, U. D.Reips, " Big Data: big gaps of knowledge in the field of internet science", International Journal of Internet Science, vol.7 (1), pp.1-5, 2012. 


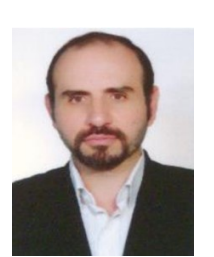

بابك سهرابى رياست دانشكده مديريت

و عضو هيأت علمى گروه مديريت فناورى

اطلاعات دانشكده مديريت دانشخاه تهر ان

و حوزهاى يزوهشى ايشان، هوش كسب

و كار، تحليل كلان داده و دادهكاوى است.

نشانى رايانامه ايشان عبارت است از:

bsohrabi@ut.ac.ir
[18] D. Gruh1, M.Nagarajan, J.Pieper , C.Robson, A. Sheth, "Multimodal social intelligence in a real-time dashboard system," The VLDB Journal The International Journal on Very Large Data Bases, vol.19 (6), pp. 825-848, 2010.

[19] B.Flesch, "Design, Development and Evaluation of a Big Data Analytics Dashboard", M.S. thesis, Copenhagen Business School, Denmark, 2014.

[20] O. Hoeber , M.Meseery , K. Kenneth Odoh , Gopi, "Visual Twitter Analytics (Vista) Temporally changing sentiment and the discovery of emergent themes within sport event tweets." Online Information Review, vol.40 (1), pp.25-41, 2016.

[21] A.Weiler, M.Grossniklaus, M. H. Scholl, "Situation monitoring of urban areas using social media data streams," Information Systems', vol.57, pp.129-141, 2016.

[22] B.Yadranjiaghdam, "Developing a Real-time Data Analytics Framework For Twitter Streaming Data.", M.S. thesis, Dept.Computer Science, East Carolina Univ., USA, 2016.

[23] B.Yadranjiaghdam, N.Pool, N.Tabrizi, "A Survey on Real-Time Big Data Analytics: Applications and Tools," In Computational Science and Com-putational Intelligence (CSCI), International Conference on, IEEE, 2016.

[24] P.Córdova, "Analysis of real time stream processing systems considering latency", 2015, Available: www.datascienceassn.org.

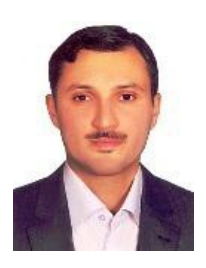

$$
\text { هدير مديد روحانى عضو هيأت علمى زَروه }
$$

SRouhani@ut.ac.ir

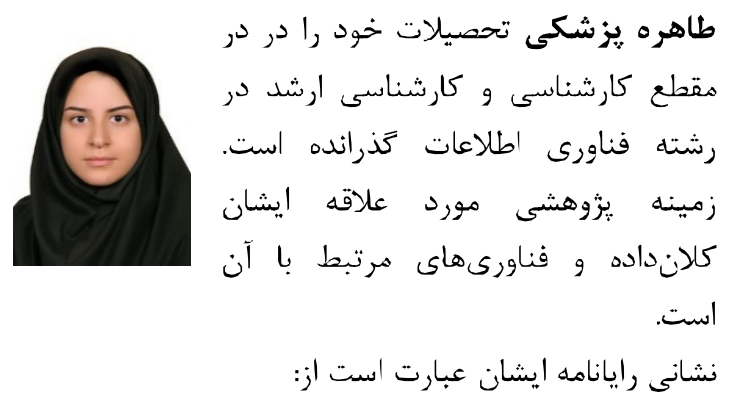

t.pezeshki@ut.ac.ir 